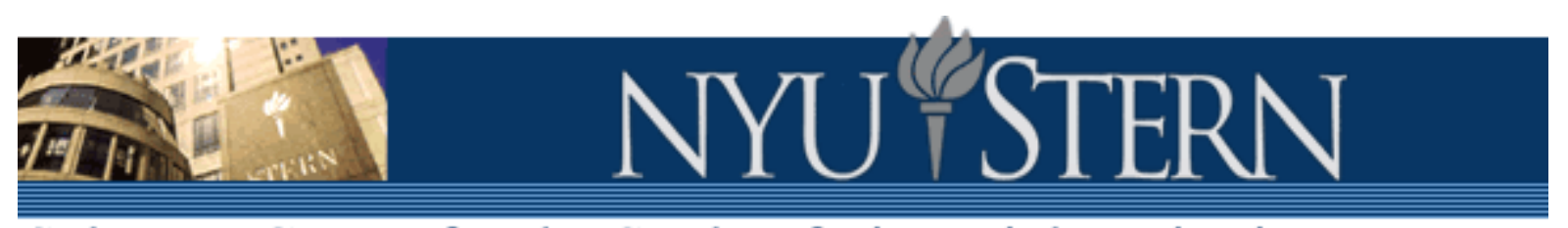

Salomon Center for the Study of Financial Institutions

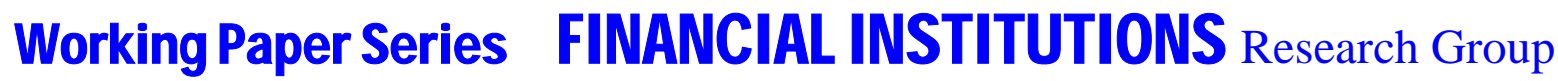

\author{
SCALING THE HIERARCHY: \\ HOW AND WHY INVESTMENT BANKS COMPETE FOR \\ SYNDICATE CO-MANAGEMENT APPOINTMENTS
}

Alexander Ljungqvist

Felicia C. Marston

William J. Wilhelm J r.

S-FI-05-02 


\section{Scaling the Hierarchy: How and Why Investment Banks Compete for Syndicate Co-Management Appointments *}

\author{
Alexander Ljungqvist \\ Stern School of Business \\ New York University \\ and $C E P R$
}

\author{
Felicia Marston \\ McIntire School of Commerce \\ University of Virginia
}

William J. Wilhelm, Jr.

McIntire School of Commerce

University of Virginia,

Saïd Business School

University of Oxford

and CEPR

September 29, 2005

\footnotetext{
${ }^{*}$ We are grateful to Mitch Petersen, Richard Rosen, and Paul Schultz for useful thoughts, and to seminar audiences at the University of Maryland, the University of Virginia, and the Federal Reserve Bank of Chicago/DePaul University joint seminar for helpful comments. We thank Yang Lu for helping us construct our social network measures. We gratefully acknowledge the contribution of Thomson Financial for providing broker recommendations data, available through the Institutional Brokers Estimate System. These data have been provided as part of a broad academic program to encourage earnings expectations research. All errors are our own.

${ }^{\dagger}$ Address for correspondence: Salomon Center, Stern School of Business, New York University, Suite 9-160, 44 West Fourth Street, New York NY 10012-1126. Phone 212-998-0304. Fax 212-995-4220. e-mail aljungqv@stern.nyu.edu.
} 


\title{
Scaling the Hierarchy: How and Why Investment Banks Compete for Syndicate Co-Management Appointments
}

\begin{abstract}
We investigate the empirical puzzle why banks pressured their analysts to provide aggressive assessments of issuing firms during the 1990s when doing so apparently had little positive effect on their chances of receiving lead-management appointments and ultimately led to regulatory penalties and costly structural reform. We show that aggressively optimistic research can attract co-management appointments and that co-management appointments eventually lead to more lucrative lead-management opportunities. Our results suggest a potential unintended anticompetitive effect of the Global Settlement if forcing greater separation of research and investment banking diminishes co-management opportunities for (and thereby potential competition from) marginal competitors in securities underwriting, especially in the debt markets.
\end{abstract}

Key words: Underwriting syndicates; Commercial banks; Glass-Steagall Act; Global Settlement; Analyst behavior.

JEL classification: G21, G24 


\section{Introduction}

In a recent paper, Ljungqvist, Marston, and Wilhelm (LMW, 2005) demonstrate that banks competing to lead manage U.S. debt or equity offerings between 1993 and 2002 did not gain competitive advantage from their research analysts providing aggressively positive assessments of the issuing company's prospects. Instead, the strength of prior underwriting and lending relationships and the candidate bank's reputation were the strongest determinants of issuers' choice among lead-bank candidates. Seemingly paradoxically, LMW also find evidence of systematically more biased research around larger and more lucrative deals and during the late 1990s bull market. But if biased research did not yield lead-management opportunities, why did some banks apparently encourage the analyst behavior that led to penalties and structural reforms imposed under the "Global Settlement" to diminish ties between investment banking and research ${ }^{1}$

We examine LMW's conjecture that such behavior predominantly reflected pursuit of comanagement opportunities among banks not likely to be appointed lead managers. Over the last decade, co-managers appeared with increasing frequency as issuers apparently sought wider analyst coverage or supplementary market making capacity (for related evidence in the context of initial public offerings (IPOs) of equity, see Corwin and Schultz (2005)). But despite their growing prevalence, comanagers exercise little influence over the transaction and enjoy modest immediate financial gains relative to lead managers. Why then would a bank seek co-management opportunities, especially if doing so places its reputation or financial capital at risk?

One plausible rationale stems from the centrality and self-reinforcing nature of reputation in the underwriting business. Issuers, especially those considering an equity offering, have an incentive to engage a reputable bank as lead manager to diminish frictions associated with asymmetric information relative to investors. The leading candidate banks for lead-management mandates derive their

\footnotetext{
${ }^{1}$ See the Securities and Exchange Commission press release at http://www.sec.gov/news/press/2003-54.htm for details.
} 
reputations from past success in this capacity. As a result, less reputable banks, or those seeking entry to securities underwriting, find it difficult to climb the ranks regardless of their true ability. Faced with this dilemma, less reputable banks might aggressively pursue co-management opportunities as a means of establishing ties with both issuers and their more reputable investment-banking peers. These ties might then serve as a stepping-stone to more lucrative lead-management opportunities in the future. The 1990s were noteworthy in this respect for the large number of commercial banks seeking entry to securities underwriting in the wake of the weakening and ultimate repeal of the Glass-Steagall Act.

This argument suggests tension in the longstanding, exclusive relationships among issuers, banks, and institutional investors that traditionally characterized the investment-banking industry. Obviously, if co-management opportunities enable significant client contact, as suggested by Corwin and Schultz (2005) in the context of IPOs, lead managers have incentive to use their influence over the issuer's comanager decision to preserve the exclusivity of their client relationship specifically and their competitive position generally. ${ }^{2}$ But the most reputable banks generally selected to lead securities offerings also have incentive to preserve investor relationships that, presumably, provide the foundation for lasting client relationships and thus their competitive standing. Here a tension exists because although the issuer benefits from a lead manager's strong investor relationships, the issuer has a private incentive, given its relatively infrequent capital market participation, to press for terms that might undermine these relationships. An issuer's demand for a (perhaps less reputable) co-manager offering aggressive (perhaps misleading) research is one plausible manifestation of this tension.

Our econometric model is designed to identify the factors influencing an issuer's choice among comanager candidates while controlling for this complex interplay among the various potential counterparties to a securities transaction. Like LMW, we treat both the decision to provide research

\footnotetext{
${ }^{2}$ See Asker and Ljungqvist (2005) for an empirical analysis of the limits to competition in investment banking in the presence of strong client relationships.
} 
coverage and the direction of the analyst's research as endogenous variables. In addition to the underwriting and lending relationship variables that appear so important in the lead manager decision, we also develop proxies for the state of relationships between the issuer's choice of lead manager and the various candidates for a co-management appointment. The model is estimated for both debt and equity offerings by U.S. issuers over the period December 1993 through June 2002 which encompasses both the demise of Glass-Steagall constraints on the entry by commercial banks into securities underwriting and the period challenged by the Global Settlement.

We find that covering the issuer's stock substantially increases the odds of winning comanagement appointments. Ahead of equity transactions, for instance, the likelihood of becoming comanager increases from $2.3 \%$ to $17.3 \%$ when the bank provides research coverage, all else equal. This result is consistent with the oft-heard conjecture that issuers "buy" analyst coverage with comanagement appointments. We also report evidence that co-management experience improves one's chances of winning more lucrative lead-management mandates, even when the issuer has an exclusive relationship with another bank. Taken together, these results suggest a potential unintended anticompetitive effect of the Global Settlement if forcing greater separation of research and investment banking diminishes co-management opportunities for (and thereby potential competition from) marginal competitors in securities underwriting.

While providing coverage appears helpful, aggressive recommendations or upgrades (relative to peer analysts) diminish the likelihood of winning a co-management mandate for equity deals. In debt offerings, aggressive relative recommendations (upgrades) increase (decrease) the likelihood of being appointed co-manager. Partitioning the sample according to whether the lead manager is either an investment bank or a commercial bank yields additional complexity among equity offerings. When the issuer designates an investment bank as its lead manager, co-management candidates continue to suffer in the competition for co-management status when their analysts aggressively upgrade 
recommendations regarding the issuer in advance of its securities offering. By contrast, aggressive recommendation upgrades increase the likelihood of winning a co-management appointment when the issuer designates a commercial bank as its lead manager. Although the evidence is not definitive, this finding is consistent with the problems identified in the Global Settlement being triggered by aggressive competition from less reputable (at least in securities underwriting) commercial banks that had less to lose by cooperating with an issuer's interest in favorable research coverage.

Although the evidence suggests that commercial bank-led deals created co-management opportunities for banks whose analysts provided relatively optimistic coverage for the issuer's stock, any such advantage appears not to have been associated with the most reputable analysts. Among candidates for co-management appointments, "all-star" analysts are generally more conservative relative to their peers around the issue at hand. In other words, the lesser prize of the co-management mandate did not elicit from among the most reputable analysts a willingness to sacrifice personal reputation on behalf of investment-banking interests.

Finally, our findings complement recent research on the structure and function of underwriting syndicates. Pichler and Wilhelm (2001) identify the syndicate as an organizational manifestation of moral hazard in team production (among investment banks) of information via networks of institutional investors. Corwin and Schultz (2005) provide support for this interpretation of the syndicate's function as well as a detailed characterization of many facets of syndicate behavior among IPOs during the late 1990s. But their focus on IPOs does not permit controlling for research coverage since it is only implicitly tied to competition for the underwriting mandate. ${ }^{3}$

Our findings for a broader sample of debt and equity offerings over a longer sample period confirm Corwin and Schultz's (2005) conclusions regarding the importance of reciprocity in the selection of

\footnotetext{
${ }^{3}$ Additional related evidence is provided by Ellis, Michaely, and O'Hara (2005) in their examination of competition for follow-on equity offerings and in Song's (2004) study of commercial bank co-management participation in debt underwriting syndicates.
} 
syndicate members. Candidate banks are more likely to become co-manager when they have participated more actively in the lead bank's recent syndicates and when the lead bank has participated more actively in recent syndicates led by the co-management candidate. We also use measures derived from social network analysis ${ }^{4}$ to show that a candidate bank's connectedness with other banks generally and with more influential banks specifically bears positively on its chances of being selected to co-manage a deal. In sum, these findings shed considerable light on the lead manager's influence over the co-management decision.

In the following section we briefly discuss the origins of the co-management function and provide an overview of trends in relationships between co- and lead managers since 1970. These provide a backdrop for our tests and inform our empirical modeling. In Section 3, we describe the data and variables used in the analysis. Section 4 outlines the econometric model. Results are reported in Section 5 and Section 6 concludes.

\section{The Evolution of the Co-Management Function}

Underwriting syndicates for corporate issues gained prominence around 1900 as the capital demands of issuers increased beyond the underwriting capacity of many individual banks. When distribution of securities offerings took weeks or months, risk-sharing considerations encouraged banks to seek co-managers with whom they could share the underwriting burden. ${ }^{5}$ Syndicate management was understood to involve the "origination" (or identification), investigation, and planning of deals. "Co-managers" worked jointly in this function (Carosso (1970)) and on more nearly equal footing than in modern syndicates where co-managers play a secondary role to (and earn smaller fees than) the lead manager. Over time, issuers valued co-managers in varying degrees as a means of promoting

\footnotetext{
${ }^{4}$ Examples of prior applications of social network analysis in a financial context include Robinson and Stuart (2004), who study the governance of strategic alliances, and Hochberg, Ljungqvist, and Lu (2005), who focus on the performance consequences of networking among U.S. venture capitalists.

${ }^{5}$ Such concerns motivated an 18-year long, exclusive co-management relationship between Goldman Sachs and Lehman Brothers beginning in 1906 with their agreement to jointly underwrite securities offerings for United Cigar Manufacturers and Sears, Roebuck \& Co. See Carosso (1970).
} 
competition among banks with which they maintained relatively exclusive relationships and for gaining access to special expertise or distribution capacity (Thackray (1971)). More recently, issuers appear to value co-managers for specialized analyst coverage or supplementary market making capacity (Corwin and Schultz (2005)).

The frequency with which underwriting syndicates are co-managed varies considerably through time. Using data from Thomson Financial's SDC database, Figure 1 illustrates the time variation in debt and equity co-management between 1970 and 2003. The long-run trend reflects an increasing (decreasing) tendency toward co-management of equity (debt) deals. Both debt and equity deals witnessed a sharp initial increase in co-management in the early 1970 s corresponding with a general decline in the exclusivity of bank-client relationships beginning in the late 1960 s. $^{6}$ Among equity deals (which include both IPOs and seasoned equity offerings (SEOs)), the fraction including one or more co-managers in the syndicate rose from $14.8 \%$ in 1970 to $58.2 \%$ in 1974 . Debt offerings witnessed a similar increase from a higher initial level of $49.6 \%$ in 1970 to $71.5 \%$ in 1973 and then tapering to $62.9 \%$ in 1974 . From that point until the late 1980 s, co-management was less common. This pattern reversed in 1990, perhaps not coincidentally in parallel with the growing participation by commercial banks in securities underwriting shown in Figure 2. Following various deregulatory steps in the late 1980s and early 1990s that culminated in the repeal of the Glass-Steagall Act in 1999, commercial banks now act as co-managers in virtually all debt transactions and around two-thirds of equity transactions (conditional on the transaction involving co-managers). ${ }^{7}$ There is thus clear evidence of entry into underwriting co-management involving well-capitalized competitors.

In addition to the increasing frequency of co-management, the 1990s witnessed declining

\footnotetext{
${ }^{6}$ Bank-client relationships suffered in the midst of technological upheaval foreshadowing both the failure of several prominent banks and restructuring at both the bank and industry levels (Morrison and Wilhelm (2005)) and retirement of senior partners for whom potential replacements were not groomed during the post-World War II period. See Thackray (1971) and Hayes (1971) on the latter point.

${ }^{7}$ The fact that commercial banks co-managed underwritten securities offerings in the 1970s and early 1980 s, as shown in Figure 2, is due to some commercial banks having retained grandfathered underwriting privileges.
} 
exclusivity in relationships among lead- and co-managers. Figure 3 plots the average number of unique co-managers with which a lead bank worked during a given year from 1970 to 2003 . The average is weighted by each lead bank's market share during that year so that the experience of more active banks is given greater weight. Focusing on equity deals, the average lead bank in 1970 had only 5.3 unique co-management partners. The number of unique co-management partners rose sharply during the 1990s peaking in 2000 at 46.3. Debt syndicates followed a similar pattern.

Assuming that lead managers prefer not to share fees and prestige with co-managers (as Corwin and Schultz (2005) suggest), it appears that market conditions during the 1990s forced banks to cede control over syndicate structure to issuing firms on a massive scale. Increasing competition from commercial banks is one plausible explanation for this change. But it is worth noting that the $1990 \mathrm{~s}$ were a period of extremely heavy securities issuance, especially during the dot-com era, in which case capacity constraints might have forced prominent banks to share the burden more widely with comanagers. Figure 3 sheds light on this point by also plotting real aggregate proceeds raised by nonfinancial U.S. issuers. The correlation between the average number of unique co-management partners and issuance activity is especially strong for equity offerings.

It is possible that Figure 3 overstates the changing nature of syndication to the extent that banks continue to involve a small handful of banks as co-managers in the vast majority of their deals and only do occasional business with a large number of peripheral banks. Figure 4 therefore shows the concentration of the average bank's syndicate relationships. For each year, we measure the strength of the relationship between bank $i$ and each of its syndication partners $j$ as the fraction of $i$ 's deals by value that involved $j$ as co-manager. We denote this $S_{i, j, t}$ (see Section 3.4 for further discussion). The sum of the squared $S_{i, j, t}$ is a Herfindahl measure of the degree of concentration in bank $i$ 's syndicate relationships during the year in question, with a value of one indicating an exclusive relationship with a single co-manager. 
Figure 4 suggests that exclusivity declined substantially between 1970 and 2003. By 2003, syndicate relationships were about as fragmented in the equity market as in the debt market, though the decline in exclusivity has been much greater in the equity market. This sharp decline suggests that the rising number of unique co-management partnerships did not simply reflect the persistence of the traditionally small number of strong syndicate relationships alongside a large number of incidental partnerships but rather a fundamental change in the exclusivity of syndication.

Historically, syndicate relationships were built on reciprocity: Banks included others in their syndicates in expectation that the favor would be returned. Figure 5 provides a broad perspective on whether the degree of reciprocity might have influenced the exclusivity of syndicate relationships during the 1970-2003 period. As in Figure 4, we denote by $S_{i, j, t}$ the strength of the relationship between banks $i$ and $j$ arising from $j$ 's participation as co-manager in syndicates lead-managed by bank $i$. Analogously, let $S_{j, i, t}$ denote the strength of the relationship between the two banks arising from i's participation in syndicates lead-managed by bank $j$. For each bank $i$ with at least ten syndication partners, we then calculate the correlation between $i$ 's $S_{i, j, t}$ and $S_{j, i, t}$ for all banks $j$ with which it had syndicate relationships. The average reciprocity measure in Figure 5 weights each bank's correlation by its underwriting market share during the year in question. Banks exhibiting weak reciprocity rarely co-manage deals lead-managed by their own co-managers and thus will exhibit zero or negative correlation.

Figure 5 suggests that average reciprocity varied considerably through time but was generally quite low and did not evidence a systematic pattern. This relatively low correlation is consistent with Carter and Manaster's (1990) interpretation of underwriter prestige reflecting a tendency toward not comanaging with a less prestigious lead manager. But, unconditionally, time variation in reciprocity sheds little light on the declining exclusivity of syndicate relationships evidenced by the increased frequency of co-management during the 1970-2003 period. 


\section{Data and Methodology}

\subsection{Sample and Data}

Our dataset is derived from two large databases: The Thomson Financial/SDC database of securities offerings, and the $\mathrm{I} / \mathrm{B} / \mathrm{E} / \mathrm{S}$ database of analyst recommendations. We use SDC to identify all debt and equity offerings by U.S. issuers completed between December 1, 1993 and June 30, 2002. We begin in 1993 because I/B/E/S tracks analyst recommendations only from Q4 1993. We end in June 2002 because the NYSE and the NASD introduced new rules for sell-side analysts in July 2002 aimed at reducing conflicts of interest between the production of investment research and investment banking (see Madureira (2004) for an overview of these regulatory changes).

We exclude non-underwritten issues; offerings that did not involve co-managers; transactions by firms classified as SIC 6000-6999 (financial institutions, etc.) or SIC 9000-9999 (government agencies, etc. $){ }^{8}$ and offerings by non-U.S. corporations. To keep the sample size manageable, we include only deals lead-managed by one of the 50 largest underwriters (by market share) during the year of the offering. Applying these filters yields 8,303 transactions ranging from IPOs to debt and equity offerings by seasoned firms including both public and private offerings and firms. The distribution of different transaction types is reported in Table I. Public common stock and public nonconvertible debt offerings account for $58.4 \%$ and $35.0 \%$ of sample transactions, respectively, but public debt dominates in dollar terms. ${ }^{9}$

LMW's sample contains 16,625 offerings. Their sample is constructed like ours, except they include offerings that do not involve co-managers (accounting for 52\% of their deals). Compared to their sample, we have relatively fewer private offerings (reflecting the fact that these rarely involve comanagers) and relatively more common stock offerings.

\footnotetext{
${ }^{8}$ Our results are qualitatively unchanged if we also exclude regulated industries (SIC 4000-4999).

${ }^{9}$ Results are unaffected if we restrict estimation to public nonconvertible debt and common stock offerings.
} 


\subsection{Sample of Candidate Banks Competing for Co-management Positions}

Estimating a bank's probability of being selected to co-manage a particular offering requires data for both the successful bank and its competitors. In the case of a debt (equity) transaction, we treat as co-management candidates the 50 banks with the largest debt (equity) underwriting market share during that year (ignoring the bank or banks that were chosen to lead-manage the transaction). ${ }^{10,11}$ Over the December 1993-June 2002 sample period, the Top 50 banks had a combined 94.9\% market share of equity co-management and a $98.1 \%$ market share of debt co-management. Note that there were fewer than 50 banks active in the debt market in 2002.

\subsection{Bank-firm Relationships}

We follow the procedure in LMW to measure the strength of bank-firm relationships based on a firm's choice of underwriters and lenders. Let $P_{j, k, t}^{d}$ denote the aggregate proceeds company $k$ raised in deals lead-managed by bank $j$ over the five years preceding quarter $t$ in deals of type $d=\{$ loan, equity, $d e b t\}{ }^{12}$ The strength of company $k$ 's type- $d$ relationship with bank $j$ then is $R_{j, k, t}^{d}=P_{j, k, t}^{d} / \sum_{j} P_{j, k, t}^{d}$. $R_{j, k, t}^{d}$ ranges from zero (no relationship) to one (when the company maintained an exclusive banking relationship). Underwriting relationships are constructed from data for all securities transactions in SDC (i.e., we include here transactions that involve no co-managers). Lending relationships are based on data derived from the Loan Pricing Corporation's (LPC's) DealScan database, which we handmatch by name (LPC's principal firm identifier) to our sample of SDC issuers. Our sample period is characterized by a substantial number of mergers and acquisitions among commercial and investment banks. In these cases, we allow banks to inherit their predecessors' relationships. For instance, after its

\footnotetext{
${ }^{10}$ This contrasts with LMW's model of the lead manager choice which focuses on the 16 largest banks as of 2002 (and their respective predecessor banks in the case of mergers). Our results are robust to their sample restriction.

${ }^{11}$ By construction, a commercial bank is treated as competing for a co-management mandate prior to the repeal of the Glass-Steagall Act only if it had a Section 20 subsidiary with Tier II securities underwriting authority granted by the Federal Reserve Board.

${ }^{12}$ All results are robust to using shorter windows.
} 
November 1997 merger, Salomon Smith Barney is treated as having relationships with both Smith Barney's and Salomon Brothers' former clients.

Many companies are related to one another so we group them on the basis of SDC's "ultimate parent CUSIP" identifier. Our relationship strength measures are constructed at the level of the corporate parent by giving the parent credit for relationships that tie its "subsidiaries" to the bank.

Table 2 reports summary statistics for $R_{j, k, t}^{d}$, broken down by whether or not the candidate bank was chosen as co-manager for the deal in question. The average successful candidate bank had leadmanaged $3.7 \%, 4.1 \%$, and $3.4 \%$ of the issuing company's equity, debt, and loan transactions by value over the prior five years, respectively. By comparison, the unsuccessful candidate banks had significantly weaker relationships with the issuing company.

\subsection{Bank-bank (Syndicate) Relationships}

We define the strength of syndicate relationships between every pair of banks $i$ and $j$ as $S_{i, j, t}^{d}=P_{i, j, t}^{d} / \sum_{j} P_{i, j, t}^{d}$ where $P_{i, j, t}^{d}$ is the aggregate proceeds from deals of type $d=\{$ equity, debt $\}$ that were lead-managed by bank $i$ and that involved bank $j$ as co-manager in the calendar year preceding year $t$. (For deals involving multiple co-managers, each is given equal credit for the proceeds.) By construction, $\sum_{j} S_{i, j, t}^{d}=1$, so we can think of $S_{i, j, t}^{d}$ as bank $j$ 's share of bank i's portfolio of comanagers in year $t-1$. We take bank mergers into account such that a lead's relationship measure with the surviving co-manager equals the sum of its relationship measures with the two pre-merger banks. We similarly account for mergers among lead managers.

Our econometric models will control both for the candidate bank's participation in the lead manager's syndicates during the preceding year, $S_{i, j, t}^{d}$, and the lead manager's participation in syndicates led by the candidate bank during the preceding year, $S_{j, i, t}^{d}$. The latter is a natural measure of the sort of reciprocity observed by Corwin and Schultz (2005) in the IPO market.

As Table 2 shows, banks that are chosen as co-managers have significantly stronger syndicate 
relationships with the lead, and vice versa, than do banks that compete unsuccessfully for comanagement assignments.

We define two further variables designed to measure a candidate bank's position in the syndication network of banks. Based on social network analysis, we view banks as better networked the more frequently they are chosen as syndication partners by other banks. Formally, we define candidate bank j's indegree as indegree ${ }_{j, t}^{d}=\sum_{i} I\left(S_{i, j, t}^{d}>0\right) /(N-1)$ where $I()$ is an indicator function evaluating whether bank $j$ ever served as co-manager in deals lead-managed by bank $i$ in year $t-1$, and $N$ is the number of banks active as lead manager that year. Indegree varies from zero (for a bank that has syndicated with no other banks) to one (for a bank that has syndicated with every bank). Table 2 shows that the average successful candidate bank had co-managed deals with $7.6 \%$ of all banks and that this is significantly greater than the average indegree of $4.0 \%$ among unsuccessful candidate.

While indegree captures whether a bank is a popular choice for co-manager, it does not allow for reputation differences among its syndication partners. For instance, a bank may achieve high indegree without ever co-managing a transaction managed by a bulge bracket bank. Assuming that status and influence derive, in part, from being networked to others who themselves are well-networked, we construct a second measure of network position called eigenvector centrality (Bonacich $(1972,1987))$. This measure weights a bank's ties to others by the importance of the banks it is tied to, where the weights are the reciprocal of the principal eigenvector $p_{t}^{d}$ of a square and symmetric matrix $A_{i, j, t}^{d}$ whose cells $(i, j)$ record whether or not banks $i$ and $j$ syndicated one or more transactions of type $d=$ $\{$ equity, debt $\}$ in the calendar year preceding year $t$. Formally, eigenvector ${ }_{j, t}^{d} \equiv E_{j, t}^{d}=\sum_{i} p_{i, j, t}^{d} E_{i, t}^{d}$. As Table 2 shows, candidate banks that are chosen as co-managers have relationships with significantly better-networked banks than do the other candidate banks.

\subsection{Bank Characteristics}

To proxy for a bank's reputation capital, we use its prior-year shares of the debt and equity 
underwriting markets (see Megginson and Weiss (1991)). We also compute each bank's share of the syndicated loan market in the calendar year before the deal in question (based on loans arranged according to DealScan) as a proxy for the bank's capacity to sweeten its bids by tying lending to capital market transactions. Following a merger, the surviving bank is credited with both predecessors' market shares. Table 2 illustrates that successful candidate banks have, on average, significantly higher equity, debt, and loan market shares than other candidate banks.

We allow for the possibility that lead banks are reluctant to work with banks outside their own reputation neighborhood by including the absolute difference between the lead's market share (in the type of security currently being issued) and that of the candidate bank. The summary statistics reported in Table 2 suggest that successful candidate banks are indeed significantly closer in market share to the lead than are the other candidate banks. In the econometric models, we interact this variable with an indicator for the top ten lead managers by market share to control for possible differences among the most reputable banks.

We also include LMW's loyalty index measuring how often a bank retains its clients in consecutive deals. ${ }^{13}$ This varies between zero and one. Consistent with LMW's findings, companies are relatively loyal, and so the average successful candidate bank has a loyalty index of 55\%. By comparison, unsuccessful candidate banks retain their clients only $41 \%$ of the time on average.

The final bank characteristic reported in Table 2 indicates that commercial banks are overrepresented among successful candidate banks: They co-manage $39.8 \%$ of sample transactions and account for $34.3 \%$ of the unsuccessful candidates. We explore several explanations for this fact in the econometric analysis but note again that commercial banks entered the securities underwriting business in an aggressive fashion during the sample period. In some cases, market share was gained through

\footnotetext{
${ }^{13}$ Define $I_{c, k}=1$ if bank $j$ acted as lead underwriter in company $k$ 's penultimate equity deal in the five years to quarter $t$, and 0 otherwise. Define $I_{r, k}=1$ if bank $j$ lead-managed company $k$ 's most recent equity deal in the same window, and zero otherwise. Then the loyalty index for bank $j$ in quarter $t$ equals $\Sigma_{k} I_{c, k} I_{r, k} / \Sigma_{k} I_{c, k}$, that is, the number of retained clients over the total number of clients.
} 
acquisition, more typically with commercial banks acquiring investment banks. We control for whether a candidate bank was involved in a merger around the time of the sample transaction by including a dummy coded 1 in the quarter of the event, and $1 / 2,1 / 3$, and $1 / 4$ in the next three quarters.

\subsection{Research Coverage, Analyst Behavior, and Analyst Reputation}

Whether a bank provides research coverage has been shown to influence the issuer's choice of lead manager (see, for instance, Cliff and Denis (2005) and Ljungqvist and Wilhelm (2005)). Research coverage may similarly influence which bank is chosen as co-manager. We classify a candidate bank as providing research coverage if one of its analysts has issued at least one recommendation in the two years preceding the transaction in hand, according to the $\mathrm{I} / \mathrm{B} / \mathrm{E} / \mathrm{S}$ recommendations database.

Successful candidate banks cover an issuing company's stock ahead of $30.1 \%$ of sample transactions, compared to only $5.8 \%$ among unsuccessful candidate banks.

LMW show that bullish recommendations or recommendation upgrades do not help a bank become lead manager, but it is an open question whether they help a bank become co-manager. Like LMW we focus on recommendations net of consensus, by subtracting from an analyst's latest recommendation in the two-year window prior to a deal the median recommendation of all analysts covering the issuer's stock. ${ }^{14}$ This ensures comparability across companies and provides a natural measure of an individual analyst's optimism. Relative recommendations range between -4 and +4 . Positive values correspond to relatively optimistic recommendations. Not surprisingly, the average and median relative recommendations in our sample are very nearly zero. $94.2 \%$ of all relative recommendations lie between -1 and +1 , so we are mostly capturing recommendations that are a notch above or below the consensus. On this measure, successful candidate banks are significantly more aggressive than other banks, though as Table 2 shows, the economic difference is small.

\footnotetext{
${ }^{14}$ Our results are robust to the following alternative consensus measures: Subtracting the mean recommendation; defining the peer group to include only sample banks (rather than all banks); or taking as the consensus the recommendations of analysts from firms that do not underwrite security offerings (such as Sanford Bernstein).
} 
We also allow for the possibility that analysts upgrade their recommendations ahead of a securities transaction in the hope of influencing the issuer's choice of co-manager. We measure relative upgrades by calculating the change between each analyst's two most recent recommendations net of the change in the consensus (i.e., median) recommendation. We require the latest recommendation to be within nine months of the deal date and the penultimate recommendation to be no older than two years. ${ }^{15}$ Relative upgrades lie between -8 and +8 , with positive values representing relatively aggressive upgrades. ${ }^{16}$ Both successful and unsuccessful candidate banks upgrade their recommendations on average ahead of deals, though the difference between their average relative upgrades is not particularly significant.

We construct three proxies for an analyst's reputation-related career concerns. The first identifies all-star analysts, i.e., those ranked top-three or runner-up in their industry in the October Institutional Investor issue preceding the transaction in hand. In Table 2, candidate banks appear a little more likely to be chosen as co-managers if they have an all-star analyst who covers the issuer's stock. The second proxy assumes that reputation derives, at least in part, from forecasting ability and so measures the analyst's relative forecast accuracy following Hong and Kubik (2003). ${ }^{17}$ By construction, this measure averages around 50\%, and analysts employed at successful candidate banks are somewhat more accurate on average than those employed at other candidate banks. The third proxy captures the fact that more senior analysts (measured by the number of years since their first appearance in the I/B/E/S

\footnotetext{
${ }^{15}$ If the analyst does not issue a new recommendation in the 275 days before the deal, we assume the prior recommendation still stands, implying a zero upgrade. If the analyst's first recommendation occurs in the 275 days prior to the deal (i.e., initiation of coverage), we assume that the bank previously was neutral toward the issuer (recommendation level 3) and measure the difference between the recommendation at coverage initiation and the assumed neutral prior recommendation. Our results are robust to excluding banks with fewer than two recommendations or, in cases in which coverage is being initiated, using the median rating among competitors rather than a "hold" rating as the basis for relative comparison.

${ }^{16}$ Since analysts cannot upgrade recommendations that are already "strong buys", our empirical models will control for strong buys. This does not drive our results.

${ }^{17}$ We compute the absolute forecast error of each analyst covering company $k$ in year $t$ as the difference between the analyst's most recent forecast of year-end earnings per share (issued between January 1 and July 1 of that year) and subsequent realized earnings, scaled by price (measured as of the prior December). Absolute forecast errors are then scaled so that the most accurate analyst scores 1 and the least accurate zero. The analyst's relative forecast accuracy in year $t$ then is her average score across the $K$ stocks she covers over years $t-2$ to $t$.
} 
earnings or recommendations files) typically make bolder recommendations (Hong et al. (2000)). Conditional on providing coverage, the average analyst has around 7.5 years of experience, with little difference between successful and other candidate banks.

\section{The Econometric Model}

Our central focus is on the determinants of a bank $j$ 's likelihood of co-managing an issuing company $k$ 's offering at time $t$ conditional on company $k$ having selected bank $i$ as its lead manager. As outlined in Section 3.2, we treat the 50 largest underwriting banks for the year in which the transaction takes place (excluding the lead manager) as potential candidates for the co-management assignment. We estimate two types of model.

\subsection{Model 1: The Effect of Aggressive Analyst Recommendations}

Model 1 relates co-manager choice to the analyst's relative recommendation (or recommendation upgrade), recognizing that when making recommendations, analysts trade off their private career concerns against any benefits co-operation with their investment banking colleagues may yield. We also take into account that recommendations are observed only if the analyst decided to cover the issuer's stock:

\section{Model 1:}

$\operatorname{Pr}($ bank $j$ co-manages company $k$ 's deal at $t \mid$ bank $j$ covers $k$ 's stock at $t)=f_{M}\left(\mathbf{R}, \mathbf{X}_{M}\right)$

$$
\begin{gathered}
\mathbf{R}=(j \text { 's recommendation for } k \text { 's stock } \mid \text { bank } j \text { covers } k \text { 's stock at } t)=f_{R}\left(\mathbf{X}_{R}\right) \\
\operatorname{Pr}(\text { bank } j \text { covers company } k \text { 's stock at } t)=f_{C}\left(\mathbf{X}_{C}\right)
\end{gathered}
$$

The explanatory variables in matrix $\mathbf{X}_{M}$ were discussed in Sections 3.3 through 3.6. Other things equal, we expect a higher probability of success among more reputable candidate banks that maintain strong relationships with the issuer and with the lead bank and which employ more reputable analysts who 
provide coverage for the issuer at time $t$. Matrices $\mathbf{X}_{R}$ and $\mathbf{X}_{C}$ contain other identifying variables as discussed below.

To keep the model relatively simple, we do not take into the account the decision whether or not to hire co-managers in the first place, which Figure 1 shows has fluctuated considerably over time. We note, however, that our results are robust to restricting the estimation sample to the largest deals, for which co-management is the norm. This makes us confident that our results are not driven by endogeneity biases arising from the failure to account for the presence of co-managers.

Equations (1) through (3) form a simultaneous equations system with endogenous switching. Following LMW, the system is estimated in two steps. In the first step, we estimate the determinants of analyst behavior, $\mathbf{R}=\{$ relative recommendation, relative upgrade $\}$, in reduced-form as a function of the costs and benefits of inflating a recommendation. Since $\mathbf{R}$ is observed only when there is coverage, we account for the resulting selectivity problem, under which ordinary least squares (OLS) yields biased and inconsistent coefficient estimates, by using Heckman's (1979) sample selection correction. In the second step, we estimate equation (1) replacing $\mathbf{R}$ with the fitted values $\hat{\mathbf{R}}$ from the first step. We adjust the probit likelihood function for selectivity bias (see Van de Ven and Van Pragg (1981)) and ensure the standard errors are estimated consistently by using the procedure derived in Murphy and Topel (1985, Section 5). In the absence of coverage, we simply estimate a single-equation probit model of equation (1), again corrected for selectivity.

Since our measures of analyst behavior $\mathbf{R}$ are normalized by the recommendation behavior of other banks, their coefficients in equation (1) indicate whether a bank is more likely to win a co-management mandate if its analyst provided a relatively more bullish recommendation for the issuer's stock, or recently upgraded the issuer's stock more aggressively, than did other banks.

We identify the system using a priori exclusion restrictions on the parameter vector, designed to satisfy the rank and order conditions that are necessary and sufficient for identification. We follow 
LMW's selection of instruments by including in equation (2) the following four proxies for the amount of bank pressure analysts might be subjected to. The first instrument is the underwriting fee earned on the deal in question relative to each bank's total prior-year underwriting fee income. ${ }^{18,19,20}$ Presumably, banks put more pressure on their analysts when competing for deals that are large relative to their normal underwriting revenue. To the extent that the size of the bonus pool increases with the bank's expected underwriting profits, this proxy will correlate with unobserved bonuses promised to analysts in return for inflated recommendations.

Our second instrument captures the idea that more active issuers have greater fee potential and thus attract more competition. We proxy for future issue activity using the firm's deal history, measured as the cumulative proceeds over the prior five years. Unlike our first instrument, deal history varies only across firms and not across banks competing for a given deal. Thus, this variable is designed to capture cross-sectional variation in how aggressive analysts as a group are ahead of a given deal.

Third, LMW argue that a "loyal" client base enables a bank to compete less fiercely and thus have less need to pressure its analysts to win underwriting mandates. The loyalty index varies across time and banks, but not across issuers.

Finally, we expect analysts to come under more pressure when the bank's underwriting revenue is declining. To capture this, we calculate the percentage change in the bank's underwriting fee revenue relative to the previous year. Like the loyalty index, this variable varies across time and banks, but not across issuers.

\footnotetext{
${ }^{18}$ Missing underwriting fee information in SDC is filled in using a regression of underwriting spreads on deal size in levels and logs (reflecting nonlinear scale economies), as well as (for debt deals) credit ratings, shelf registration status, industry effects, prior issue experience, and the maturity of the bond. The results are not sensitive to alternative approaches, such as assuming all missing SEO fees equal 5\% and all missing debt fees equal $1 \%$.

${ }^{19}$ For some banks, prior-year fee revenue is often small or zero. To avoid results being driven by extreme outliers, we measure the relative underwriting fee as $-\ln (1+$ lagged fee revenue/fee on deal). The minus sign ensures that a larger value for this variable means a more attractive deal worth competing hard for.

${ }^{20}$ Since a co-manager's fee is not publicly disclosed, we use the fee earned by the syndicate as a whole on the assumption that the division of fees is relatively stable across deals.
} 


\subsection{Model 2: The Effect of Providing Research Coverage}

Model 2 relates co-manager choice to the analyst's decision whether or not to publish research on the issuer's stock - regardless of the direction or strength of the analyst's recommendation. We treat the research coverage decision, $\mathbf{C}$, as endogenous:

\section{Model 2:}

$$
\begin{gathered}
\operatorname{Pr}(\text { bank } j \text { co-manages company } k \text { 's deal at } t)=f_{M}\left(\mathbf{C}, \mathbf{X}_{M}\right) \\
\mathbf{C}^{*}=\operatorname{Pr}(\text { bank } j \text { covers company } k \text { 's stock at } t)=f_{C}\left(\mathbf{X}_{C}\right)
\end{gathered}
$$

where the star indicates an unobserved latent variable whose realizations are observed as binary outcomes. Equation (3) is the same as in Model 1. As is standard in simultaneous equations where both dependent variables are dichotomous, equations (3) and (4) are estimated as a seemingly unrelated bivariate probit model (Greene (2003); Fabbri, Monfardini, and Radice (2004)). To ensure identification, we include six instruments in equation (3). The main one is the fraction of company $k$ 's Fama-French (1997) industry that the bank's analysts provide coverage for. The broader a bank's existing coverage of an industry, the lower the cost of covering company $k$ 's stock, and so the more likely it is that the bank's analyst will publish research about company $k$. In addition, we control for the size of the fee on the deal in hand and the company's capacity for generating future fee income, both of which presumably increase the economic benefit to providing coverage if issuers base their comanager choice on the provision of research. Finally, we control for whether and where the company's stock is listed and how long it has traded.

\section{Estimation Results}

\subsection{The Coverage Model}

Table 3 replicates in our sample LMW's model of the likelihood that an analyst working for bank $j$ 
covers firm $k$ 's stock ahead of a deal at time $t$ (equation (3)), estimated separately for equity and debt deals. Similar to LMW, we find that a firm's stock is more likely to be covered prior to a capital market transaction, the stronger its relationship with the bank, the larger the bank's equity underwriting market share, after the bank has acquired another bank, when the bank's analyst already covers a large fraction of the firm's sector, if that analyst is an all-star, the larger the firm's fee-generating capacity, and the more mature the firm. Ahead of debt (but not equity) deals, coverage is less likely for unlisted firms and the larger the size of the fee on the deal relative to the bank's prior-year underwriting fee income. In many instances, especially in the debt specification, the magnitude of these effects is smaller for commercial banks, which, all else equal, were less likely to provide coverage.

The two coverage models shown in Table 3 condition whether we observe analyst behavior ahead of equity or debt deals, which we turn to next.

\subsection{The Analyst Behavior Models}

Table 4 presents estimation results for the analyst behavior equation (2) in structural form, for each of the two proxies for analyst behavior. The equations are estimated separately for debt and equity deals, and conditioned on the coverage decision (i.e., equation (3)) using joint MLE. Like LMW, we include in the relative upgrade specifications a dummy variable equaling one if the penultimate recommendation was already a strong buy, ruling out a further upgrade (the coefficients, which are significantly negative as expected, are not reported). ${ }^{21}$

The statistically significant coefficients estimated for the equity models generally conform with our priors. Co-management candidates that have strong equity underwriting relationships with the issuer and with the lead manager are associated with less aggressive analyst behavior. Similarly, the significant negative coefficient estimated for eigenvector centrality indicates that well networked

\footnotetext{
${ }^{21}$ As a robustness check, we repeat our analysis on a subsample that drops all cases in which the penultimate recommendation was a strong buy, so that the relative upgrade specifications no longer require inclusion of the dummy. All results are qualitatively unaffected.
} 
banks are also associated with less aggressive analyst behavior. These results are consistent with strong relationships diminishing the need to compete for business via aggressive analyst upgrades.

A bank's lending capacity provides a second dimension on which banks might compete for underwriting business. The statistically significant negative coefficient estimated for a bank's loan market share during the prior calendar year suggests that lending capacity substitutes for any benefits it might derive from aggressive analyst upgrades.

All-star analysts are less likely to be associated with aggressive upgrades as one would expect if analysts value their reputations. More accurate forecasting ability and greater analyst seniority are associated with more aggressive recommendation behavior suggesting that aggressive behavior reflects, at least in part, legitimate boldness among more competent analysts. On the other hand, when the payoff to aggressive behavior is potentially larger, as measured by the relative size of the fee on the deal at hand and the log of the issuer's proceeds from issuance during the preceding five years, both analyst recommendations and upgrades are more aggressive. Finally, banks with rising fee income are associated with less aggressive analyst behavior.

The debt sample differs largely in the fact that stronger client (especially lending) relationships and privileged positions in the syndication network generally are associated with more aggressive analyst behavior among co-management candidates. Moreover, candidates with strong reputations in debt underwriting, as measured by the bank's debt market share during the preceding year, also are associated with more aggressive analyst behavior. On the other hand, a strong reputation for equity underwriting is associated with less aggressive analyst behavior which - if the greatest prestige in securities underwriting derives from success in equities underwriting - provides a rationale for the apparent unwillingness of some candidate banks to sacrifice their reputations by pressuring their analysts toward producing biased research.

But controlling for the candidate's equity market reputation, why would a bank with a strong debt 
market reputation and strong client and peer relationships promote more aggressive behavior among its analysts? One plausible explanation rests on rising competition from commercial banks entering the underwriting business primarily through the debt markets. Most commercial banks were less active in the provision of research coverage throughout much of the sample period. Thus aggressive research coverage might have been perceived as providing a competitive edge to the sub-bulge bracket investment banks with relatively strong client and peer relationships but also facing the greatest initial exposure to commercial bank competition.

Similar to the findings of LMW, the Staiger and Stock (1997) instrument test suggests that the relative recommendation specification of the equity model (column (1)) yields weak instruments for the second-stage estimation of Model 1. As a consequence, the relative recommendation specification of the equity model discussed in the next section may not improve on a one-step estimator that treats relative recommendations as exogenous. Moreover, the second-step standard errors for this specification may be imprecise because the Murphy-Topel correction is partly based on the first-step covariance matrix.

\subsection{The Determinants of the Probability of Becoming a Co-manager}

\subsubsection{Equity Transactions}

Table 5 summarizes the results from estimating the co-manager choice models for equity transactions. The first three columns relate to Model 1, the simultaneous equations system with endogenous switching described in Section 4.1, which is directly analogous to the lead manager choice model used by LMW. Conditional on a bank providing research coverage, we estimate two specifications, one for each measure of analyst behavior. These are shown in columns (1) and (2). Column (3) completes Model 1 by reporting parameter estimates in the absence of coverage. Column (4) reports results from estimating Model 2, the bivariate probit model described in Section 4.2. Here, we relate co-manager choice to the analyst's decision whether or not to publish research on the issuer's 
stock - regardless of the strength of the analyst's recommendation - treating the research coverage decision as endogenous. The explanatory power in all four columns is quite good, in view of the pseudo- $R^{2}$ which range from $18.9 \%$ in column (3) to $23.1 \%$ in column (4).

Conditional on a bank providing research coverage, Model 1 indicates that both aggressive relative recommendations and upgrades reduce a bank's chances of becoming co-manager. The latter effect is both statistically and economically significant: A one standard deviation increase in relative upgrades reduces the likelihood of becoming co-manager from the conditional expectation given coverage of $38.1 \%$ to $35.6 \%$. This pattern is identical to that found by LMW in their lead manager choice model for equity transactions.

By contrast, the results from Model 2 shown in column (4) indicate that opting to publish research on the issuer's stock has a strongly positive and statistically significant bearing on a candidate bank's chances of winning a co-management appointment. ${ }^{22}$ The effect is very large economically: Provision of coverage increases the likelihood of becoming co-manager from the unconditional mean of $2.3 \%$ to $17.3 \%{ }^{23}$ Taken together, these results suggest that equity co-managers are selected for their willingness to cover the issuing firm, not for their ability to pressure their analysts to provide excessively optimistic coverage.

The strength of bank-firm relationships has a positive and statistically significant effect on a candidate bank's chances of being appointed co-manager. This is true regardless of whether we treat the coverage decision as endogenous (Model 2) or, in the event of coverage, treat the direction of the candidate's research as endogenous (Model 1), though the economic effect is proportionately larger in Model 2 than in Model 1. In sum, having an underwriting or lending relationship with the issuer increases one's chances of being appointed a co-manager in the event that the lead-management

\footnotetext{
${ }^{22}$ This is true also when we widen the coverage window to include initiations after a transaction, in order to capture both actual coverage and possibly implicit promises of future coverage.

${ }^{23}$ The unconditional expectation is a little higher than 1 in 50 because some deals involve more than one co-manager.
} 
mandate goes to another bank.

In all four columns, the coefficients estimated for the candidate bank's participation in the lead bank's syndicates during the preceding year are positive and statistically significant. This is consistent with lead managers having favorable influence at the margin on the issuer's decision whether to select a co-manager with whom the lead manager has worked frequently in the past. The positive coefficients for the lead bank's participation in syndicates led by a co-management candidate during the preceding year suggest an element of reciprocity of the sort identified by Corwin and Schultz (2005) in the context of IPOs in the late 1990s. Economically, these effects are comparable in magnitude to the effects of strong bank-firm relationships.

The coefficients for indegree and eigenvector centrality indicate that both syndicate relationships with a wide variety of different banks and those with the most prominent banks have independent, positive, and statistically significant effects on a candidate bank's chances of being appointed a comanager. Eigenvector has the larger economic effect, with a one standard deviation increase nearly doubling the likelihood of becoming co-manager in column (4).

The control variables for candidate-bank and lead-bank characteristics shed light on potential tension among issuers, lead managers, and prospective co-managers. First, we see that a comanagement candidate's debt and equity underwriting market shares do not affect its chances of becoming co-manager for equity transactions. Assuming that issuers always prefer more reputable banks, other things equal, this result suggests that either lead managers exercise influence in the comanagement decision that cuts against their more reputable competitors or that the most reputable banks do not accept co-management appointments.

Second, if the preceding result suggests that lead managers steer issuers away from more reputable competitors in the selection of a co-manager, their efforts are undermined when the candidate bank has significant lending capacity. A candidate's loan market share during the preceding year has a positive 
and statistically significant effect on the probability of being selected as co-manager in all but the relative recommendation specification of Model 1. Since commercial banks were the predominant source of loans during the sample period, this finding is consistent with the idea that commercial banks used their lending capacity to gain co-management appointments.

The next set of coefficients suggests that a co-management candidate is less viable when there is a wide gap between its reputation (as proxied by its equity underwriting market share) and that of the lead bank. A one standard deviation increase in the absolute difference in market shares is nearly enough to reduce the bank's chances of becoming co-manager to zero, all else equal. We also interact this variable with a dummy variable indicating whether the lead bank is among the top ten in equity market share and find that the most reputable banks are either more willing or have little choice but to work with substantially less reputable co-managers. The latter explanation is more plausible if the most reputable banks are less inclined to play second fiddle when a highly reputable competitor is chosen ahead of them to lead a deal.

The final control for bank characteristics identifies whether the candidate bank had recently merged with another bank. The significantly positive coefficients for this variable in columns (3) and (4) suggest that banks can to some extent buy deal flow through acquisitions.

Finally, candidate banks employing more reputable analysts are more likely to be chosen as comanager. In column (2), the effect of the all-star status of the analyst who provides coverage for the issuer's stock is positive and marginally significant, as is her seniority. In columns (3) and (4), where we include cases of noncoverage, we recode the all-star variable to capture whether the candidate bank employed an all-star analyst who provided coverage for the issuer's Fama-French industry at the time of the deal in hand. Employing an all-star analyst significantly improves a candidate bank's chances of becoming co-manager, and the economic magnitude of the effect in column (4) is similar to that of strong bank-firm relationships. 
In summary, the equity co-manager choice models yield evidence of a variety of considerations that likely reflect both the issuer's preferences and those of the pre-determined lead manager. Other things equal, existing coverage of the issuer's stock appears to serve co-management candidates well while aggressive recommendation upgrades do not. These conclusions hold for the sample at large. Below we show that the latter conclusion is sensitive to whether the lead manager is a commercial bank or an investment bank. Banks that have a history of dealing with the issuer also are more likely to be appointed co-managers conditional on their not having been selected to lead the transaction. Thus, issuers with multiple bank relationships appear to "rotate" through their relationship banks from deal to deal, with the non-winning banks being selected as co-managers. Other things equal, more reputable banks are not more likely to be appointed co-manager except in so far as their reputation derives from lending capacity, as would more typically be the case for a commercial bank. The co-manager choice also appears to be influenced by a co-management candidate's relationship with the lead manager and the extent to which the candidate is well connected among its peers in general.

\subsubsection{Debt Transactions}

To conserve space, we focus only on the main differences between the results for the debt and equity samples. The most notable difference is the positive and statistically significant effect of the analyst variable in column (1) of Table 6: Aggressive recommendation levels significantly increase a candidate bank's chances of becoming co-manager, by 2.8 percentage points from the $8.2 \%$ probability conditional on coverage. By contrast, LMW find that aggressive recommendation levels significantly reduce a candidate bank's chance of becoming lead manager in debt offerings. Our finding may explain why banks appear to have inflated their recommendation levels ahead of large debt transactions in the late 1990s, even though doing so did not boost their chances of lead-managing these deals - instead, the "reward" may have been selection as co-manager.

The negative and statistically significant coefficient estimated for relative upgrades in column (2) 
suggests that issuers were swayed more by banks having a history of aggressively recommending their stock than by relatively recent (and perhaps more opportunistically motivated) upgrades. Economically and statistically, however, this effect is quite small. Furthermore, compared to the equity sample in Table 5, providing research coverage ahead of debt transactions increases a bank's chances of becoming co-manager in column (4) by only a relatively small amount, from the unconditional likelihood of $3.4 \%$ to $6.4 \%$, all else held equal.

The candidate bank's debt (equity) market share now has a positive (negative) and significant effect in the no-coverage (column (3)) and endogenous coverage specifications (column (4)). Like LMW, we interpret this as evidence of specialization, that is, large debt underwriters are more likely to be included in a debt syndicate than are large equity underwriters.

The only other significant difference involves the all-star dummy, which is negative and significant in the no-coverage (column (3)) and endogenous coverage specifications (column (4)). One interpretation is that the most reputable banks, employing the top analysts, will not stoop to comanaging debt deals. This seems plausible given that narrower spreads on debt transactions make comanagement for them even less attractive in this context than in equity deals.

\subsubsection{Differences Across Time and Syndicates Types}

We now investigate how the determinants of co-manager choice differ across time and syndicate types. For the former, we split the sample into two periods, 1993-1997 and 1998-June 2002. The end of the first period corresponds with the de facto repeal of the Glass-Steagall Act revealed by the approval of Citicorp's 1998 acquisition of Salomon Smith Barney. We also consider three distinct syndicate types: Those for small $(<\$ 100$ million $)$ versus large transactions $(\geq \$ 100$ million); those lead-managed by investment banks versus commercial banks; and those where the lead manager provided active research coverage versus no coverage in the run-up to the deal.

Table 7 reports the coefficients for the effect of relative upgrades on the likelihood of a candidate 
bank becoming co-manager for each sample split (separately for equity and debt transactions), suppressing all other Model 1 coefficients. The harmful effects of aggressive upgrades appear to be concentrated in the 1993-1997 period, for both equity and debt deals, with negative but statistically insignificant effects in the 1998-2002 period. Like LMW's findings for the determinants of the leadmanagement choice, we find no evidence that aggressive upgrades increased a candidate's chances of (in our case) being appointed a co-manager. In contrast to LMW, we do not find a statistically negative effect during the 1998-2002 period. Thus, while aggressive analyst behavior was costly in the pursuit of lead-management mandates, it was not a costly strategy for co-management candidates, consistent with our conjecture that banks pressured their analysts in the late 1990s not in the hope of becoming lead manager but to gain co-management mandates.

Transaction size has no effect on the influence of analyst behavior in the equity sample, but large debt transactions are associated with a significantly reduced likelihood of an aggressive bank becoming co-manager (mirroring the results for the sample as a whole).$^{24}$ When the sample is split by lead manager type, an interesting result emerges in the equity sample: When the lead manager is an investment bank, a candidate bank is significantly less likely to become co-manager when its analyst aggressively upgrades the issuer's stock; when the lead manager is a commercial bank, the opposite is true. Thus only among equity deals led by commercial banks do we find any evidence of aggressive analyst behavior positively influencing a bank's chances of being appointed co-manager. Finally, whether or not the lead manager actively covers the issuer's stock has no impact on the effect of the candidate bank's upgrade behavior.

Tables 8 through 11 report the results of estimating Model 2 in each of the sample splits. We first

\footnotetext{
${ }^{24}$ The results for the largest deals in Tables 7 and 9 mirror those for the sample as a whole in Tables 5 and 6 . As comanagement of large deals is more nearly the norm rather than the result of a discretionary choice, we do not believe our results are driven by endogeneity biases arising from the failure to incorporate the decision whether or not to hire comanagers in the first place.
} 
review the effects that are consistently statistically significant across the four sample splits. For equity transactions, the provision of research coverage, strong bank-firm relationships, strong syndicate relationships (though not necessarily reciprocity), being well-connected in terms of both indegree and eigenvector centrality, large loan market shares, and being in the lead manager's reputation neighborhood all significantly increase a candidate bank's chances of joining the syndicate as comanager. The same is true for debt transactions, with the exception of the provision of research coverage, which has no significant effect when the lead manager is a commercial bank. Mergers always have a positive effect but significance varies across the sample splits.

These similarities mask some noteworthy differences in economic significance. In equity transactions, the benefit to a candidate bank of providing coverage is roughly twice as large in the later period than in the earlier period and when the lead manager provides coverage than when it does not. The former result is consistent with anecdotes suggesting that research coverage became an increasingly important determinant of syndicate decisions and the increasing frequency of co-managed deals. The latter result, that co-management coverage is especially important when the lead manager chosen by the issuer provides coverage, suggests that some issuers place substantially more emphasis than others on gaining research coverage through their syndicate appointments. In debt transactions, the benefit of providing coverage is more than three times larger in small deals than in large ones, and it is positive only when the lead manager is an investment bank.

For both equity and debt transactions, lending relationships are much more important in large than in small deals, which is consistent with larger equity and debt issuers being larger users of syndicated loans. For debt transactions, bank-bank relationships have become more important over time and matter more when the lead manager is an investment bank. Reciprocity appears to have gone out of fashion in the latter period for both equity and debt deals. For all transactions, the importance of having strong connections with well-connected others (eigenvector centrality) has at least doubled over 
time and appears especially beneficial in large deals. Finally, lead managers' reluctance to syndicate with banks of substantially lower reputational standing has increased tremendously over time, especially in the debt market, and in the equity market is particularly pronounced when the lead manager is an investment bank.

The effects of employing an all-star analyst to cover the issuer's industry and of the candidate bank's equity and debt market shares differ across the sample splits. In equity deals, all-star analysts only boost a bank's selection chances in the 1998-2002 period. They are more beneficial in large deals, when the lead manager does not provide coverage, and when the lead manager is an investment bank. In debt deals, having an all-star analyst in the issuer's industry is beneficial only in small deals; in all other sample splits, its effect is either significantly negative or insignificant.

Finally, in equity transactions, large equity underwriters were at an advantage in the 1993-1997 period but at a disadvantage in the 1998-2002 period and when the lead manager was a commercial bank. Large debt underwriters were at a disadvantage in the earlier period, in small transactions, and when the lead manager did not cover the issuer's stock, and at an advantage in large deals and when the lead manager did cover the issuer's stock. In debt transactions, large equity underwriting market share either had no or a significantly negative effect, while large debt underwriting market share always appears to help a candidate bank become a debt co-manager. On the whole, these results are consistent with erosion of market power among leading investment banks as commercial banks entered the underwriting business first in the debt and later in the equity market.

\subsection{Does Co-management Yield Lead-management Opportunities?}

In this section we investigate the conjecture in the introduction that ties with issuers gained through co-management opportunities might serve as a stepping-stone to more lucrative lead-management opportunities. To do so, we estimate a version of Model 2 for the lead-management choice while 
controlling for a candidate bank's past co-management relationships with a prospective issuer. ${ }^{25}$ We do so in the complete sample of deals lead-managed by the 50 largest underwriters during 1993-2002, that is, we include deals that did not involve co-managers.

The results shown in columns (1) and (3) of Table 12 show that, as conjectured, banks are indeed more likely to win lead-management mandates if they have previously established strong ties with the issuer through co-management. This is true for both equity and debt transactions, and in each case, banks benefit from having acted both as debt and equity co-managers. The remaining coefficients confirm LMW's conclusions in the context of our Model 2 specifications. Banks are more likely to win both equity and debt lead-management mandates, the stronger their lead-management underwriting relationships, the larger their market share in the respective market, the greater their presence in the syndicated loan market, and following mergers. Providing research coverage is especially beneficial ahead of debt transactions, while employing an all-star analyst who covers the issuer's sector helps win equity mandates. In addition, banks that are well-connected in terms of high indegree or eigenvector centrality are more likely to be chosen as lead-managers. Economically, the eigenvector measure has the largest effect, nearly doubling the probability of selection in the equity sample and increasing it by more than $50 \%$ in the debt sample.

These specifications might be misleading if issuers "rotate" through a set of multiple relationship banks from deal to deal, with the non-winning banks being selected as co-managers, because then the same banks will have strong lead and strong co-management ties to the issuer. In columns (2) and (4), we restrict the samples to the 1,851 equity and 1,704 debt deals in which the issuer had a single leadmanagement relationship and ask whether strong co-management relationships help a candidate bank “crack" such exclusive firm-bank relationships. Consistent with LMW, we find persistence in

\footnotetext{
${ }^{25}$ We could equally estimate the effect of co-management relationships on lead appointments in the context of Model 1. However, Model 2 adds nuance to the results reported in LMW's version of Model 1 by including coverage.
} 
relationships in the sense that the relationship bank is significantly more likely to be chosen as the lead. But there is switching: Fully 711 of the 1,851 equity mandates and 872 of the 1,704 debt mandates are won by a bank other than the relationship bank, and the positive and significant coefficients in columns (2) and (4) confirm that a candidate bank is more likely to become lead manager in an equity (debt) deal if it has served as co-manager on the issuer's prior equity (debt) deals. ${ }^{26}$

These results provide a plausible explanation for why banks compete for the apparently modest rewards associated with co-management mandates. In a setting where reputational considerations impose substantial barriers to entry, success in attracting co-management appointments provides an effective means of scaling the hierarchy, even in the presence of strong bank-firm relationships.

\section{Conclusion}

We began the paper by asking why banks pressured their analysts to provide aggressively positive assessments of issuing firms during the 1990s when doing so apparently had little positive effect on their chances of receiving lead-management appointments and ultimately led to penalties and costly structural reform. Following the conjecture offered by Ljungqvist, Marston, and Wilhelm (2005) we explore whether such behavior improved a bank's chances of being appointed co-manager which, in turn, might have opened the door to more lucrative lead-management appointments. Our findings generally support this conjecture.

Consistent with the belief that issuers buy analyst coverage with co-management appointments, simply providing coverage has a strong positive effect on a bank's chances of being appointed a comanager. Aggressive recommendations or upgrades (relative to peer analysts) diminish chances of being appointed co-manager for equity offerings but aggressive recommendations improve chances of being appointed co-manager for debt offerings. When we partition the sample according to whether the

\footnotetext{
${ }^{26}$ The unconditional means tell a similar story: Ahead of equity deals, successful candidate banks had average equity comanagement relationships of 0.157 , compared to 0.013 for the unsuccessful banks. The corresponding means ahead of debt deals are 0.086 and 0.006 . The differences are significant with $t$-statistics of 44.6 and 41.6 , respectively.
} 
lead manager was an investment bank or a commercial bank, we also find evidence that aggressive recommendations among co-management candidates served their interests in pursuit of equity deals when the lead manager was a commercial bank. Finally, banks that attract an issuer's co-management appointments are more likely to win more lucrative lead-management mandates in the future, even in the hardest-to-win cases of exclusive relationships with another bank.

In summary, our findings suggest a causal chain consistent with the reputation-intensive nature of the securities underwriting business. Aggressive analyst behavior appears to have played some role in attracting co-management appointments. Aggressive behavior was concentrated most heavily among less reputable banks at a time when heavily capitalized commercial banks were aggressively pursuing securities underwriting business. The effect was strongest in the debt markets where commercial banks first gained their toehold and in equity markets only when commercial banks acted as lead managers. If there is merit in this interpretation, our results also suggest a potential unintended anti-competitive effect that might arise from the Global Settlement's separation of research and investment banking. Specifically, if separation of these functions compromises the ability to compete for co-management appointments via analyst coverage, this provision of the Settlement has potential for bearing most heavily on marginal competitors fighting to climb the securities underwriting ranks. 


\section{References}

Asker, John, and Alexander Ljungqvist, 2005, Information disclosure as a limit to competition in investment banking, unpublished working paper, New York University.

Bonacich, Philip, 1972, Factoring and weighting approaches to status scores and clique identification, Journal of Mathematical Sociology 2, 113-120.

Bonacich, Philip, 1987, Power and centrality: A family of measures, American Journal of Sociology 92, 1170-1182.

Carosso, Vincent P., 1970, Investment Banking in America: A History, Cambridge: Harvard University Press.

Carter, Richard B., and Steven Manaster, 1990, Initial public offerings and underwriter reputation, Journal of Finance 45, 1045-1067.

Cliff, Michael T., and David J. Denis, 2004, Do IPO firms purchase analyst coverage with underpricing? Journal of Finance 59, 2871-2901.

Corwin, Shane, and Paul Schultz, 2005, The role of IPO underwriting syndicates: Pricing, information production, and underwriter competition, Journal of Finance 60, 443-486.

Ellis, Katrina, Roni Michaely, and Maureen O’Hara, 2005, Competition in investment banking: Proactive, reactive, or retaliatory? Unpublished working paper, Cornell University.

Fabbri, Daniele, Chiara Monfardini, and Rosalba Radice, 2004, Testing exogeneity in the bivariate probit model: Monte Carlo evidence and an application to health economics, unpublished working paper, University of Bologna.

Fama, Eugene, and Kenneth French, 1997, Industry costs of equity, Journal of Financial Economics 43, 153-194.

Greene, William H., 2003, Econometric Analysis, Prentice Hall.

Hayes, Samuel L., 1971, Investment banking: Power structure in flux, Harvard Business Review 49, 136-152.

Heckman, James J., 1979, Sample selection bias as a specification error, Econometrica 47, 153-162.

Hochberg, Yael, Alexander Ljungqvist, and Yang Lu, 2005, Whom you know matters: Venture capital networks and investment performance, Journal of Finance, forthcoming.

Hong, Harrison, and Jeffrey D. Kubik, 2003, Analyzing the analysts: Career concerns and biased earnings forecasts, Journal of Finance 58, 313-351.

Hong, Harrison, Jeffrey D. Kubik, and Amit Solomon, 2000, Security analysts' career concerns and the herding of earnings forecasts, RAND Journal of Economics 31, 121-144. 
Ljungqvist, Alexander, Felicia Marston, and William J. Wilhelm, 2005, Competing for securities underwriting mandates: Banking relationships and analyst recommendations, Journal of Finance, forthcoming.

Ljungqvist, Alexander, and William J. Wilhelm, 2005, Does prospect theory explain IPO market behavior?, Journal of Finance 60, 1759-1790.

Madureira, Leonardo, 2004, Conflicts of interest, regulations, and stock recommendations, Working paper, University of Pennsylvania.

Megginson, William L., and Kathleen A. Weiss, 1991, Venture capitalist certification in initial public offerings, Journal of Finance 46, 879-903.

Morrison, Alan, and William J. Wilhelm, 2005, The demise of investment banking partnerships: Theory and evidence, Unpublished working paper, University of Virginia.

Murphy, Kevin M., and Robert H. Topel, 1985, Estimation and inference in two-step econometric models, Journal of Business and Economic Statistics 13, 370-379.

Pichler, Pegaret, and William J. Wilhelm, 2001, A theory of the syndicate: Form follows function, Journal of Finance 56, 2237-2264.

Robinson, David T. and Toby E. Stuart, 2004, Network effects in the governance of biotech strategic alliances, Unpublished working paper, Columbia University.

Song, Wei-Ling, 2004, Competition and coalition among underwriters: The decision to join a syndicate, Journal of Finance 59, 2421-2444.

Staiger, Douglas, and James H. Stock, 1997, Instrumental variables regression with weak instruments, Econometrica 65, 557-586.

Thackray, John, 1971, Investment banking breaks formation: Why account-switching is accelerating, Corporate Financing (May/June).

Van de Ven, W.P.M.M., and B.M.S. Van Pragg, 1981, The demand for deductibles in private health insurance: A probit model with sample selection, Journal of Econometrics 17, 229-252. 
Figure 1. Fraction of equity and debt deals that involve co-managers.

The graph shows the fraction of equity and debt transactions that involve one or more co-managers between 1970 and 2003 as reported by Securities Data Corporation, after excluding transactions by firms classified as SIC 6000-6999 (financial institutions, etc.) or SIC 9000-9999 (government agencies, etc.).

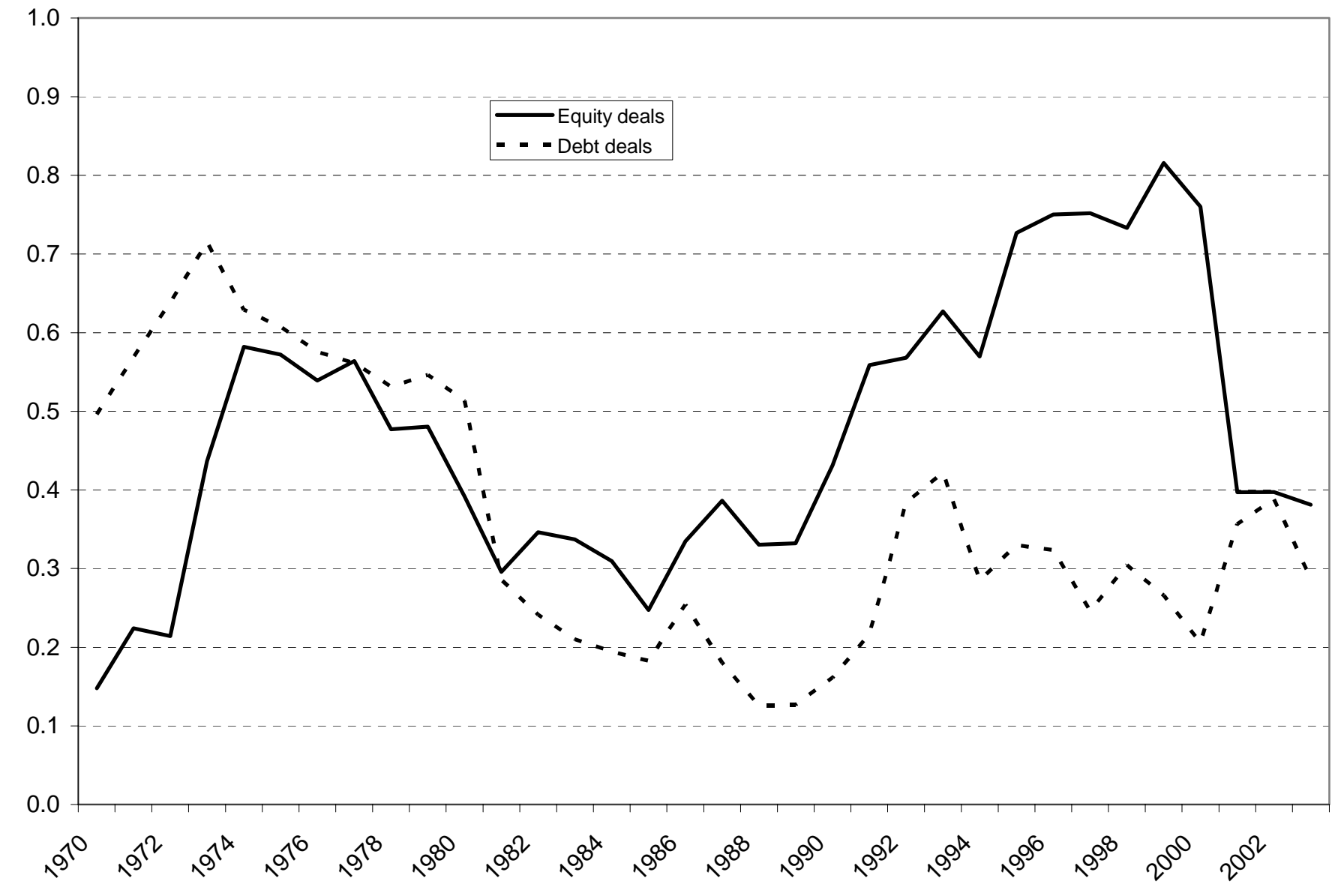


Figure 2. Fraction of equity and debt deals that involve commercial banks as co-manager.

The graph shows the fraction of equity and debt transactions that involve one or more commercial banks as co-managers between 1970 and 2003 as reported by Securities Data Corporation, after excluding transactions by firms classified as SIC 6000-6999 (financial institutions, etc.) or SIC 9000-9999 (government agencies, etc.) as well as deals that do not involve co-managers.

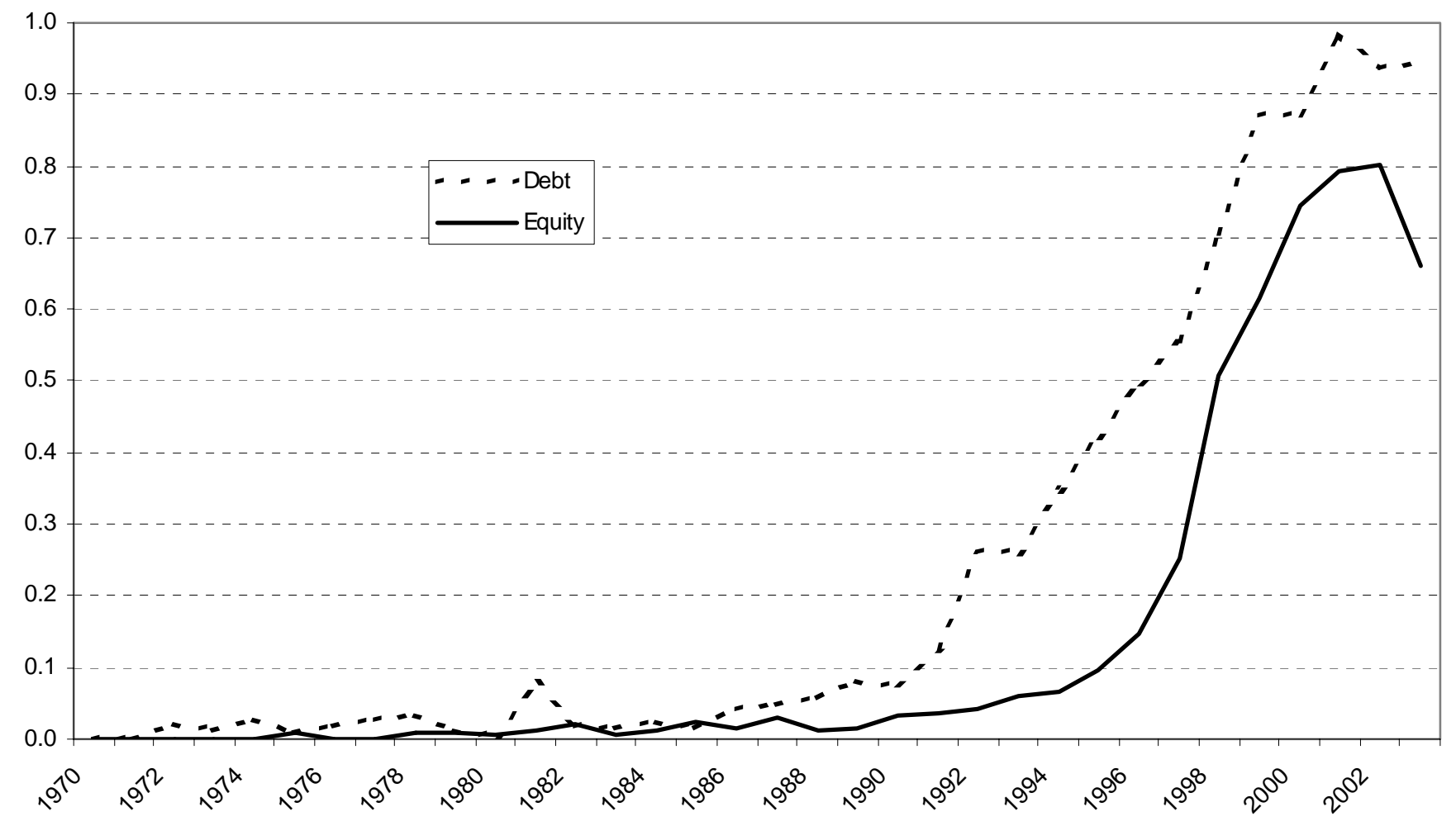


Figure 3. Weighted average number of co-management partners.

The figure plots the number of unique co-managers that the average bank has syndication relationships with in a given year against the real aggregate proceeds raised by non-financial issuers in the U.S. (in dollars of 2005 purchasing power, deflated using the GDP price deflator). We compute a weighted average of co-management partners using each bank's underwriting market share as weights. This gives more weight to the number of partners of the most active underwriters.
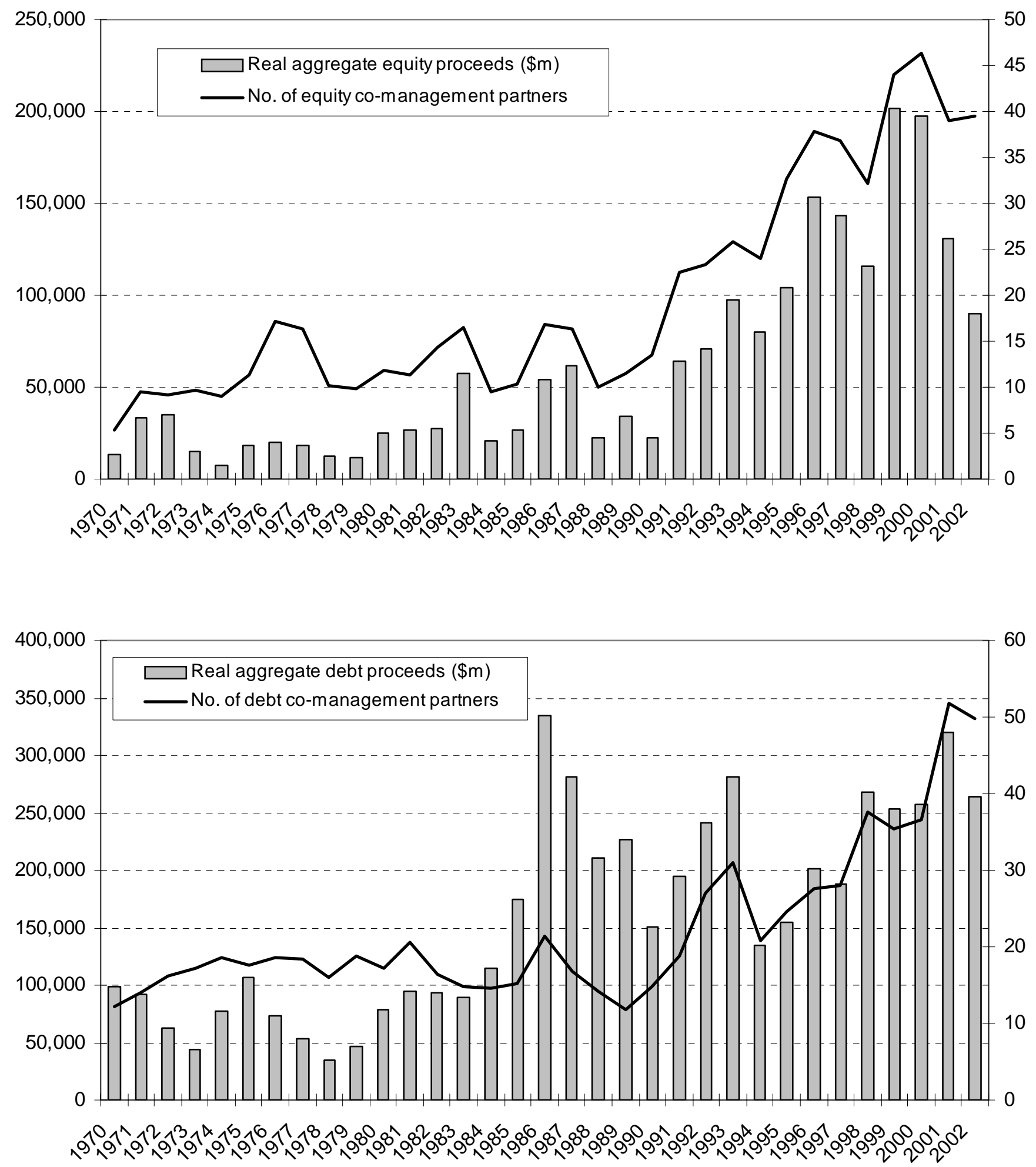
Figure 4. Concentration of syndicate relationships.

Bank $i$ 's syndicate relationship with every bank $j$ is measured as the fraction of bank $i$ 's deals by value that involve bank $j$ as comanager that year (with equal credit given to each co-manager in deals involving multiple co-managers). For instance, if bank $i$ lead-managed a single deal worth $\$ 30$ million with three co-managers, then each co-manager is credited with $\$ 10$ million and bank i's syndicate relationship with each of the three co-managers is $1 / 3$. The concentration of bank $i$ 's syndication relationships in a given year is computed as the sum of its squared syndication relationships (that is, a Herfindahl index). This varies from zero (infinitely many syndication partners) to one (a relationship with a single syndication partner). The figure plots the weighted average concentration, using each bank's underwriting market share as weights. This gives more weight to the concentration of the most active underwriters' syndication networks.

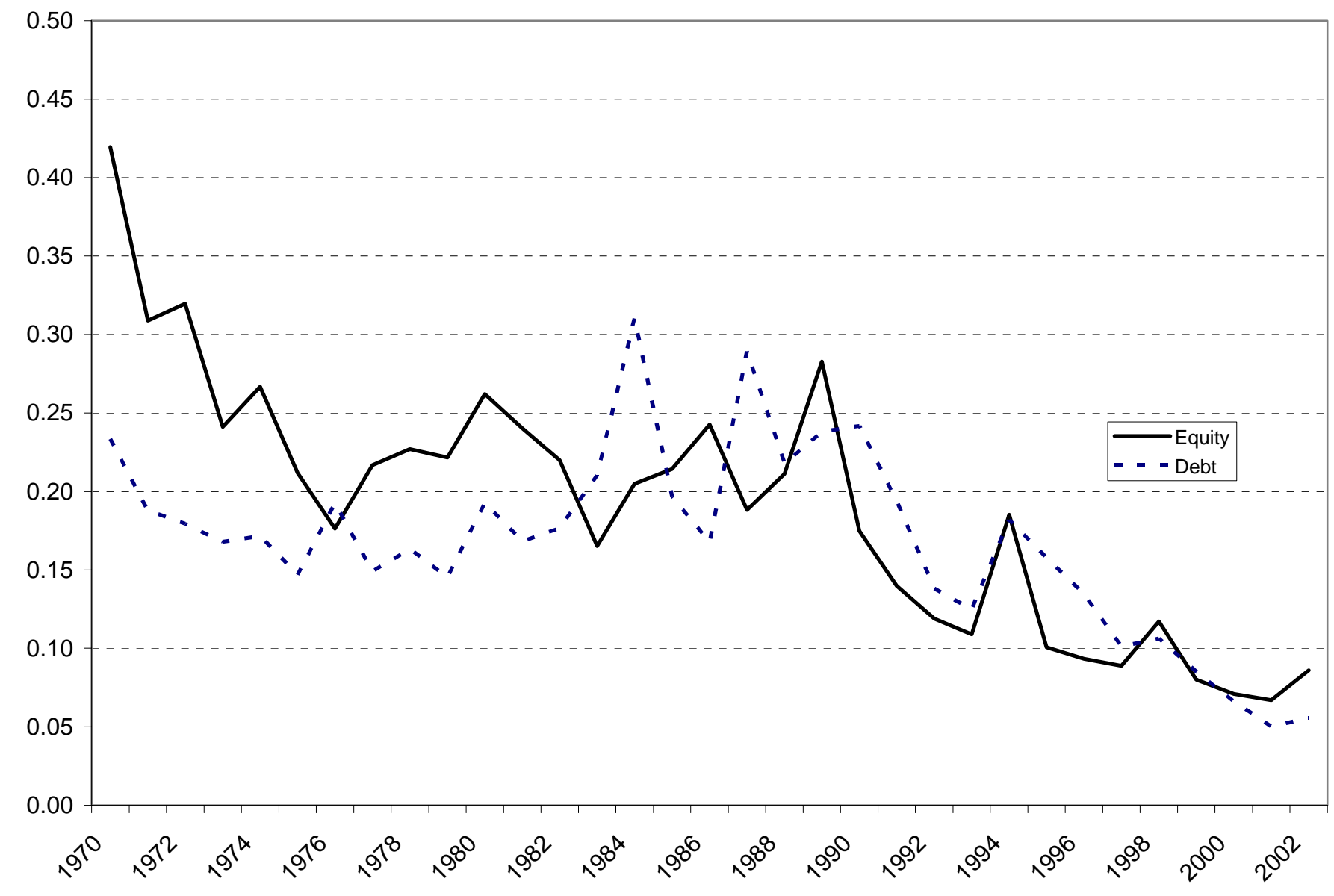


Figure 5. Weighted reciprocity.

Let $S_{i, j, t}$ denote the strength of the relationship between banks $i$ and $j$ arising from $j$ 's participation as co-manager in syndicates lead-managed by bank $i$ (computed as in Figure 4 and as defined in Section 3.4). Analogously, let $S_{j, i, t}$ denote the strength of the relationship between the two banks arising from i's participation in syndicates lead-managed by bank $j$. To measure whether syndicate relationships are reciprocal, we correlate bank $i$ 's $S_{i, j, t}$ and $S_{j, i, t}$ for all banks $j$ that it had syndicate relationships with. To illustrate, a bank that never co-manages deals lead-managed by its own co-managers will have a negative correlation, indicating that its syndicate relationships are not reciprocal. The figure graphs the weighted average relationship correlation (or reciprocity) using each bank's underwriting market share as weights. This gives more weight to the reciprocities of the most active underwriters.

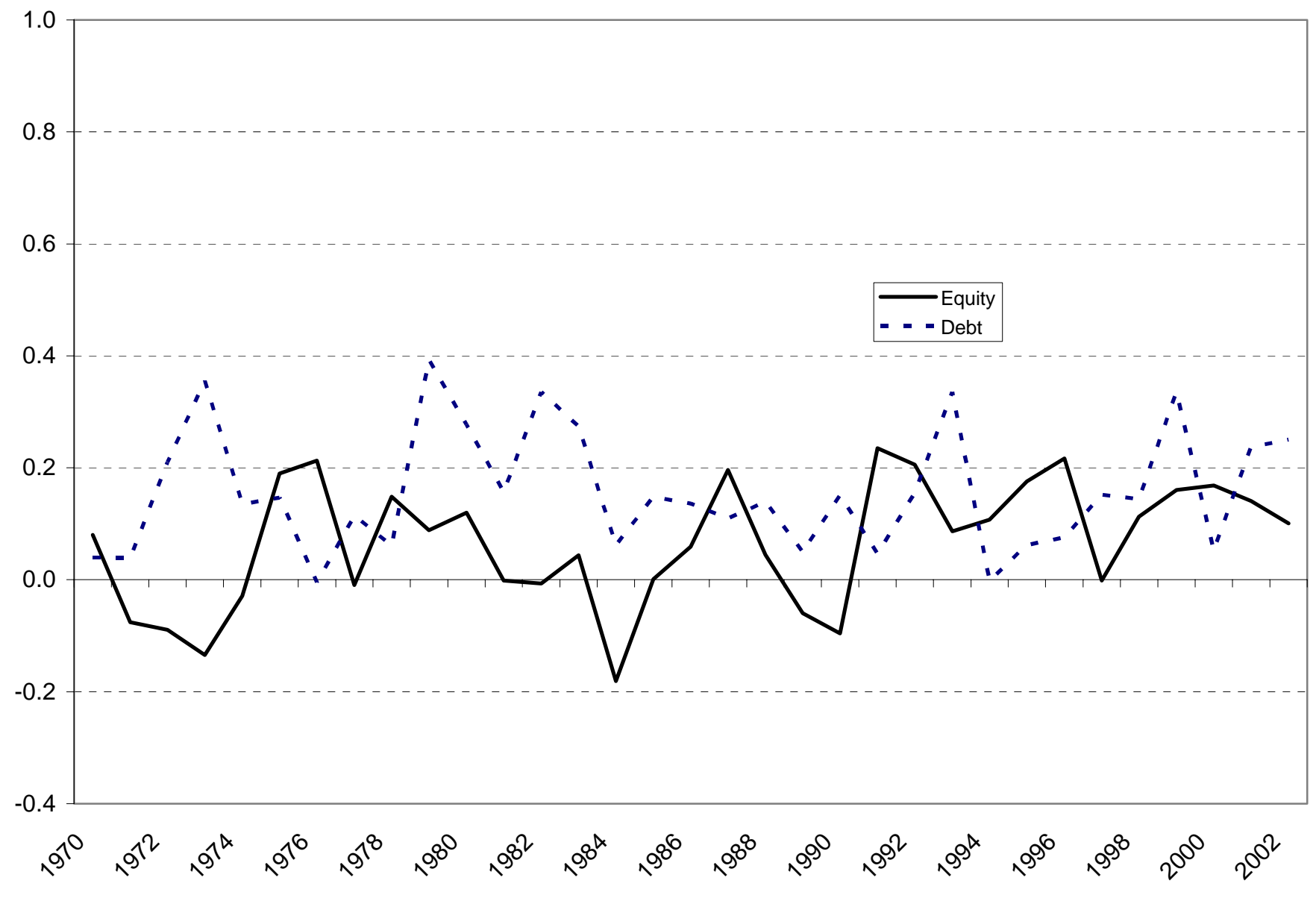


Table 1. The Sample of Capital-Raising Transactions.

The sample consists of 8,303 capital-raising transactions completed between December 1, 1993 and June 30, 2002 as reported by Securities Data Corporation, after excluding non-underwritten issues; offerings that did not involve comanagers; transactions by firms classified as SIC 6000-6999 (financial institutions, etc.) and SIC 9000-9999 (government agencies, etc.); and offerings by non-U.S. corporations. We also require that each deal was lead-managed by one of the 50 largest underwriters active that year. Research coverage in the last column requires that the lead manager's research department publish at least one research report about the issuing company in the two years preceding the transaction. All currency amounts are in nominal terms.

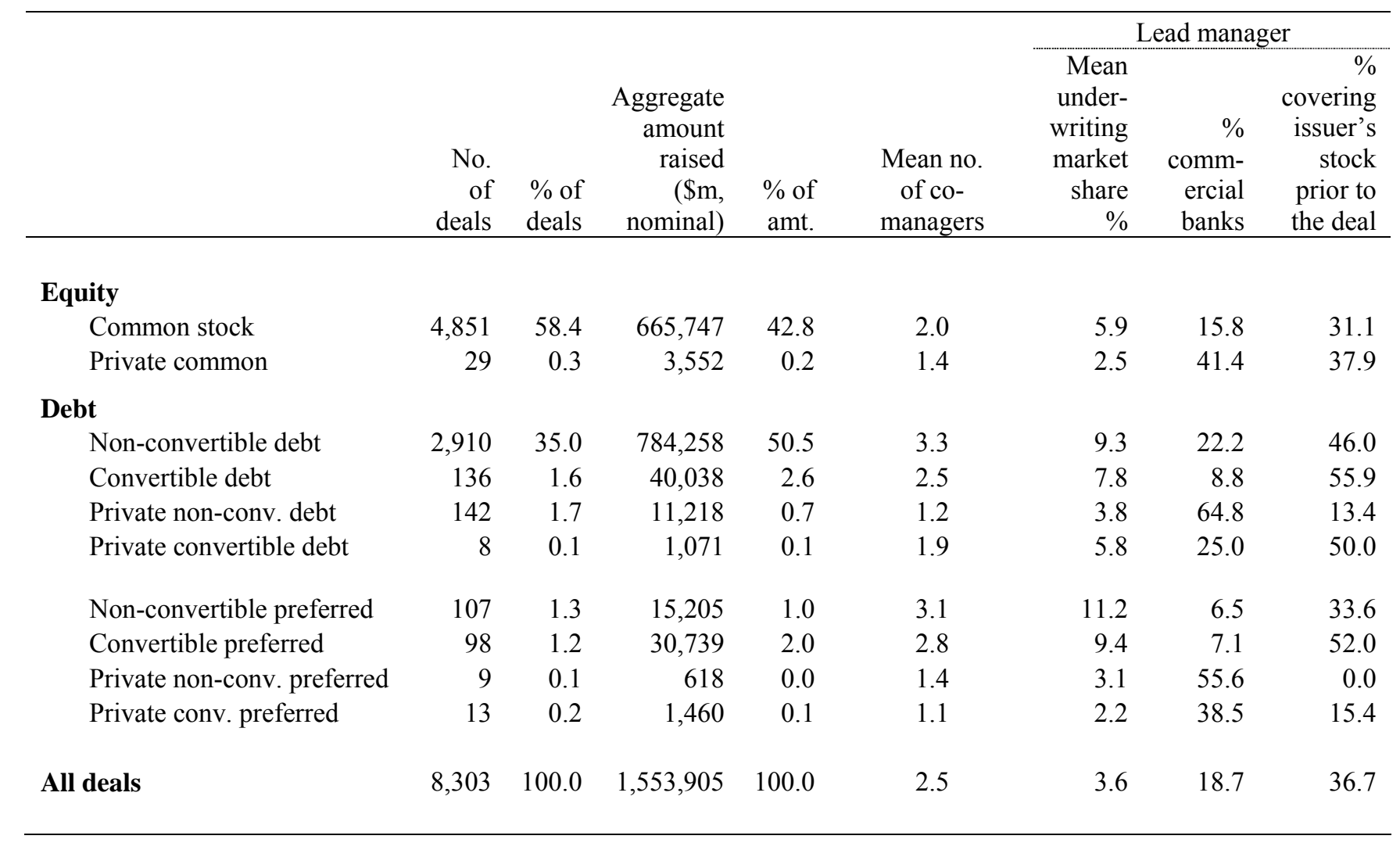




\section{Table 2. Descriptive Statistics.}

The unit of observation in this table is a bank-deal pair. The dataset consists of 8,303 deals, for each of which the 50 largest banks are deemed to compete to be chosen as co-manager (except for debt deals in 2002, when there were fewer than 50 banks in the market). This gives a sample of 414,760 bank-deal pairs. The column headed 'co-managers' refers to the 20,106 bank-deal pairs involving banks that were awarded co-management assignments, while the column headed 'other candidate banks' refers to the 394,654 bank-deal pairs involving banks that were eligible to compete for but were not chosen as co-manager. For each bank-deal pair, we report the main explanatory variables used in the econometric models. A candidate bank's prior relationships with the issuing company and with the lead manager are based on their joint capital raising histories over the five years preceding the deal in question. To measure a candidate bank's position in the network of syndicate banks, we compute indegree (the number of unique banks it has syndicated with in the prior calendar year, normalized by the number of possible syndication partners) and eigenvector centrality (a recursive measure of indegree that weights syndication ties by how well networked each syndication partner is). The loyalty index measures how often a bank retains its underwriting clients in consecutive deals. A bank is deemed to provide research coverage if its research department has published at least one research report about the issuing company in the two years preceding the transaction. Relative recommendations measure the candidate bank's recommendation level relative to consensus (by subtracting from the bank's most recent recommendation the median recommendation of all other banks covering firm $i$ in the 730-day window before i's next deal). Relative upgrades are computed as a bank's recommendation change for firm $i$ less the median change of other sample banks. By construction, relative recommendations lie between -4 and +4 while relative upgrades lie between -8 and +8 . Positive values denote relatively aggressive recommendations or upgrades. All-stars are analysts ranked as a top-three or runner-up analyst in their industry in the most recent Institutional Investor survey preceding the deal. Relative forecast accuracy is a measure of the analyst's forecast accuracy for the issuer's stock, relative to other analysts. It is constructed as in Hong and Kubik (2003) and ranges from 0 to 100, with a higher number indicating greater forecast accuracy. As a proxy for seniority, we compute the number of years since the analyst first appeared in the $\mathrm{I} / \mathrm{B} / \mathrm{E} / \mathrm{S}$ database. We lose some observations for relative forecast accuracy and analyst seniority because not all analysts disclose their name in the $\mathrm{I} / \mathrm{B} / \mathrm{E} / \mathrm{S}$ recommendations file. The last column provides $t$-tests of differences in means/fractions comparing winning to losing banks.

\begin{tabular}{lccc}
\hline & Co- & $\begin{array}{c}\text { Other } \\
\text { candidate } \\
\text { banks }\end{array}$ & t-test \\
\hline Bank-firm relationships & & & \\
mean bank's share of firm's equity deals prior 5 years (\%) & 3.7 & 0.3 & $-77.4^{* * *}$ \\
mean bank's share of firm's debt deals prior 5 years (\%) & 4.1 & 0.4 & $-96.5^{* * *}$ \\
mean bank's share of firm's loans prior 5 years (\%) & 3.4 & 0.4 & $-74.7^{* * *}$ \\
Bank-bank relationships & & & $-128.6^{* * *}$ \\
mean bank's participation in lead's prior-year syndicates (\%) & 5.1 & $-52.2^{* * *}$ \\
mean lead's participation in bank's prior-year syndicates (\%) & 4.5 & 1.5 & $-146.1^{* * *}$ \\
mean indegree centrality (\%) & 7.6 & 2.0 & $132.7^{* * *}$ \\
mean eigenvector centrality (\%) & 23.8 & 4.0 & $-91.9^{* * *}$ \\
Bank characteristics & & 13.0 & $-108.6^{* * *}$ \\
mean bank's equity market share prior calendar year (\%) & 3.9 & 1.6 & $-38.5^{* * *}$ \\
mean bank's debt market share prior calendar year (\%) & 4.4 & 1.6 & $11.5^{* * *}$ \\
mean bank's loan market share prior calendar year (\%) & 0.5 & 0.1 & $-57.0^{* * *}$ \\
mean abs(lead's market share - bank's market share) (\%) & 6.3 & 6.7 & $-16.0^{* * *}$ \\
mean loyalty index (\%) & 55.0 & 41.0 & 34.3 \\
fraction commercial banks (\%) & 39.8 & & $-131.6^{* * *}$ \\
Research coverage, analyst behavior, and analyst reputation & & & $-10.8^{* * *}$ \\
fraction with coverage (\%) & 30.1 & $-2.8^{* *}$ \\
mean relative recommendation & 0.103 & -0.018 & $-6.7^{* * *}$ \\
mean relative upgrade & 0.127 & 0.094 & $-4.6^{* * *}$ \\
fraction of issuers covered by all-star analysts (\%) & 26.6 & 22.5 & $2.0^{*}$ \\
mean relative forecast accuracy & 51.7 & 51.0 & \\
mean analyst's seniority (years in I/B/E/S database) & 7.5 & & \\
& & & \\
\hline
\end{tabular}


Table 3. Strategic Coverage Decisions.

We estimate the determinants of the coverage decision using probit MLE. This corresponds to equation (3). The coverage decision determines whether or not we observe the analyst's behavior in subsequent tables. Therefore, the estimation results in subsequent tables are conditioned on the coverage decision using the Heckman (1979) MLE framework, where the coverage decision, analyst behavior, and co-manager choice are jointly estimated. For the purpose of illustrating what determines coverage, this table shows the results of two stand-alone probits, for equity and debt deals respectively. The dependent variable is an indicator equal to one if the bank's analyst covers the issuer's stock at any point during the two years preceding the deal. Since commercial banks in our sample period are generally less likely to provide research coverage, we interact the main explanatory variables with a dummy equaling one for commercial banks. Banks that cover a larger fraction of an issuer's industry are more likely to cover the issuer as well. We control for this using the fraction of the issuing firm's Fama-French (1997) industry that is covered by bank $j$, measured over the three-year window ending in the year of the deal. The dummy for mergers is coded 1 in the quarter of the event, and $1 / 2,1 / 3$, and $1 / 4$ in the next three quarters. Intercepts and year effects are not shown. Standard errors are shown in italics. We use ${ }^{* * *},{ }^{* *}$, and ${ }^{*}$ to denote significance at the $0.1 \%, 1 \%$, and $5 \%$ level (two-sided), respectively. The number of observations is 244,624 in the equity model and 170,136 in the debt model.

\begin{tabular}{|c|c|c|c|c|}
\hline & \multicolumn{2}{|c|}{ Probit 1: Equity deals } & \multicolumn{2}{|c|}{ Probit 2: Debt deals } \\
\hline & & $\begin{array}{l}\text { commercial } \\
\text { ank dummy }\end{array}$ & & $\begin{array}{l}\times \text { commercial } \\
\text { bank dummy }\end{array}$ \\
\hline \multicolumn{5}{|l|}{ Bank-firm relationships } \\
\hline bank's share of firm's debt deals prior 5 years & $\begin{array}{l}0.680^{* * *} \\
0.089\end{array}$ & $\begin{array}{c}-0.266 \\
0.178\end{array}$ & $\begin{array}{l}0.420^{* * *} \\
0.060\end{array}$ & $\begin{array}{c}-0.434^{*} \\
0.143\end{array}$ \\
\hline bank's share of firm's equity deals prior 5 years & $\begin{array}{l}1.594^{* * *} \\
0.056\end{array}$ & $\begin{array}{c}-0.099 \\
0.118\end{array}$ & $\begin{array}{l}0.387^{* * *} \\
0.051\end{array}$ & $\begin{array}{c}-0.029 \\
0.146\end{array}$ \\
\hline bank's share of firm's loans prior 5 years & $\begin{array}{l}0.636 \\
0.414\end{array}$ & $\begin{array}{l}0.088 \\
0.423\end{array}$ & $\begin{array}{l}0.452 \\
0.295\end{array}$ & $\begin{array}{c}-0.066 \\
0.304\end{array}$ \\
\hline \multicolumn{5}{|l|}{ Bank characteristics } \\
\hline bank's equity market share prior calendar year & $\begin{array}{l}1.269^{* * *} \\
0.365\end{array}$ & $\begin{array}{l}3.612^{* * *} \\
0.994\end{array}$ & $\begin{array}{c}-0.361 \\
0.251\end{array}$ & $\begin{array}{l}5.474^{* * *} \\
0.673\end{array}$ \\
\hline bank's debt market share prior calendar year & $\begin{array}{l}-2.302^{* * *} \\
0.356\end{array}$ & $\begin{array}{r}-0.469 \\
0.593\end{array}$ & $\begin{array}{c}-1.538^{* * *} \\
0.297\end{array}$ & $\begin{array}{l}0.675 \\
0.494\end{array}$ \\
\hline bank's loan market share prior calendar year & $\begin{array}{r}-1.007 \\
4.465\end{array}$ & $\begin{array}{l}4.233 \\
4.477\end{array}$ & $\begin{array}{c}-8.110^{* *} \\
3.071\end{array}$ & $\begin{array}{l}9.165^{* *} \\
3.094\end{array}$ \\
\hline$=1$ if bank involved in merger & $\begin{array}{l}0.306^{* * *} \\
0.048\end{array}$ & $\begin{array}{r}-0.019 \\
0.061\end{array}$ & $\begin{array}{l}0.277^{* * *} \\
0.040\end{array}$ & $\begin{array}{l}-0.238^{* * *} \\
0.050\end{array}$ \\
\hline fraction of firm's Fama-French industry covered & $\begin{array}{l}4.053^{* * *} \\
0.068\end{array}$ & $\begin{array}{c}-0.118 \\
0.127\end{array}$ & $\begin{array}{l}3.443^{* * *} \\
0.050\end{array}$ & $\begin{array}{l}1.710^{* * *} \\
0.085\end{array}$ \\
\hline$=1$ if bank has all-star analyst covering Fama-French industry & $\begin{array}{l}0.197^{* * *} \\
0.019\end{array}$ & $\begin{array}{c}-0.095^{* *} \\
0.035\end{array}$ & $\begin{array}{l}0.490^{* * *} \\
0.016\end{array}$ & $\begin{array}{c}-0.371^{* * *} \\
0.029\end{array}$ \\
\hline $\begin{array}{l}\text { Firm characteristics } \\
\text { underwriting fee on deal / bank's prior-year fee income }\end{array}$ & $\begin{array}{l}0.053^{* * *} \\
0.007\end{array}$ & $\begin{array}{c}-0.010 \\
0.011\end{array}$ & $\begin{array}{l}-0.055^{* * *} \\
0.004\end{array}$ & $\begin{array}{l}0.082^{* * *} \\
0.006\end{array}$ \\
\hline $\log$ firm's $\$$ equity or debt proceeds prior 5 years & $\begin{array}{l}0.141^{* * *} \\
0.003\end{array}$ & $\begin{array}{r}-0.007 \\
0.004\end{array}$ & $\begin{array}{l}0.043^{* * *} \\
0.002\end{array}$ & $\begin{array}{l}-0.010^{* * *} \\
0.002\end{array}$ \\
\hline log time since IPO & $\begin{array}{l}0.450^{* * *} \\
0.009\end{array}$ & & $\begin{array}{l}0.181^{* * *} \\
0.007\end{array}$ & \\
\hline$=1$ if firm is not listed & $\begin{array}{r}-0.077 \\
0.099\end{array}$ & & $\begin{array}{l}-0.686^{* * *} \\
0.033\end{array}$ & \\
\hline \multicolumn{5}{|l|}{ Diagnostics } \\
\hline LR test: all coefficients $=0\left(\chi^{2}\right)$ & \multicolumn{2}{|c|}{$18,994^{* * *}$} & \multicolumn{2}{|c|}{$34,046^{* * *}$} \\
\hline Pseudo- $R^{2}$ & \multicolumn{2}{|c|}{$25.1 \%$} & \multicolumn{2}{|c|}{$27.4 \%$} \\
\hline
\end{tabular}


Table 4. Analyst Behavior.

The dependent variables are relative recommendations and relative upgrades. These are observed only when the bank covers the stock, so we estimate Heckman (1979) selection models using joint MLE. Representative results for the associated selection equation are shown in Table 3. The estimation results in this table are reported in structural form. The reduced forms used to generate instruments for the models in Tables 5 and 6 include also the exogenous variables from the lead-bank equation and are not shown. The relative upgrade models include a dummy equal to one if the previous recommendation was a strong buy; the coefficients, which are negative and significant, are not shown. Analyst characteristics are defined as in Table 2. Indegree and eigenvector are orthogonalized against each other to avoid multicollinearity problems. The bubble dummy equals 1 for deals completed in 1999 and 2000. The four 'bank pressure proxies' measure the size of potential rewards for liquidating reputation capital, or equivalently the amount of pressure that might be put on an analyst to deliver a favorable recommendation. These are the instruments we use to identify the system. The more lucrative the client - as measured by the fee on the deal in question relative to the bank's prior-year fee pool, and by the firm's deal history - the more tempted the analyst to inflate the recommendation. Banks with more 'loyal' clients are less likely to resort to inflating analyst forecasts. We also control for time-variation in the bank's underwriting fee revenue, on the assumption that decreases in fee income (relative to the previous year) may prompt more aggressive analyst behaviour in an effort to reverse the decline. Intercepts are not shown. Standard errors are shown in italics. We use ${ }^{* * *},{ }^{* *}$, and ${ }^{*}$ to denote significance at the $0.1 \%, 1 \%$, and $5 \%$ (two-sided), respectively. The Staiger and Stock (1997) test is a test of the strength of the instruments. It is based on an F-test of the joint significance of the instruments in the reduced-form models. The critical value for strong instruments is 10 . The number of observations where the bank provides research coverage is 8,002 in the equity model and 18,796 in the debt specifications.

\begin{tabular}{|c|c|c|c|c|}
\hline & \multicolumn{2}{|c|}{ Equity } & \multicolumn{2}{|c|}{ Debt } \\
\hline Relative... & $\begin{array}{l}\text { recomm. } \\
\text { (1) }\end{array}$ & $\begin{array}{l}\text { upgrades } \\
\text { (2) }\end{array}$ & $\begin{array}{l}\text { recomm. } \\
\text { (3) }\end{array}$ & $\begin{array}{l}\text { upgrades } \\
\text { (4) }\end{array}$ \\
\hline \multicolumn{5}{|l|}{ Bank-firm relationships } \\
\hline bank's share of firm's debt deals prior 5 years & $\begin{array}{l}0.093 \\
0.071\end{array}$ & $\begin{array}{r}-0.053 \\
0.075\end{array}$ & $\begin{array}{l}0.354^{* * *} \\
0.051\end{array}$ & $\begin{array}{l}0.089 \\
0.049\end{array}$ \\
\hline bank's share of firm's equity deals prior 5 years & $\begin{array}{c}-0.009 \\
0.045\end{array}$ & $\begin{array}{c}-0.139^{* *} \\
0.0478\end{array}$ & $\begin{array}{l}0.168^{* * *} \\
0.041\end{array}$ & $\begin{array}{l}0.134^{* * *} \\
0.040\end{array}$ \\
\hline bank's share of firm's loans prior 5 years & $\begin{array}{l}0.100 \\
0.096\end{array}$ & $\begin{array}{l}0.164 \\
0.102\end{array}$ & $\begin{array}{l}0.463^{* * *} \\
0.083\end{array}$ & $\begin{array}{l}0.161^{*} \\
0.079\end{array}$ \\
\hline \multicolumn{5}{|l|}{ Bank-bank relationships } \\
\hline bank's participation in lead's prior-year syndicates & $\begin{array}{l}0.065 \\
0.172\end{array}$ & $\begin{array}{c}-0.373^{*} \\
0.182\end{array}$ & $\begin{array}{c}-0.006 \\
0.150\end{array}$ & $\begin{array}{l}0.047 \\
0.145\end{array}$ \\
\hline lead's participation in bank's prior-year syndicates & $\begin{array}{l}0.208 \\
0.136\end{array}$ & $\begin{array}{l}0.265 \\
0.144\end{array}$ & $\begin{array}{l}0.076 \\
0.084\end{array}$ & $\begin{array}{l}0.071 \\
0.081\end{array}$ \\
\hline bank's indegree centrality & $\begin{array}{c}-0.004 \\
0.005\end{array}$ & $\begin{array}{l}0.007 \\
0.005\end{array}$ & $\begin{array}{l}-0.014^{* * *} \\
0.003\end{array}$ & $\begin{array}{l}0.011^{* * *} \\
0.003\end{array}$ \\
\hline bank's eigenvector centrality & $\begin{array}{c}-0.082 \\
0.141\end{array}$ & $\begin{array}{c}-0.373^{*} \\
0.150\end{array}$ & $\begin{array}{l}0.523^{* * *} \\
0.097\end{array}$ & $\begin{array}{l}0.248^{* *} \\
0.094\end{array}$ \\
\hline \multicolumn{5}{|l|}{ Bank characteristics } \\
\hline bank's equity market share prior calendar year & $\begin{array}{c}-0.150 \\
0.408\end{array}$ & $\begin{array}{c}-0.023 \\
0.430\end{array}$ & $\begin{array}{l}-1.193^{* * *} \\
0.227\end{array}$ & $\begin{array}{c}-0.530^{*} \\
0.218\end{array}$ \\
\hline bank's debt market share prior calendar year & $\begin{array}{l}0.616 \\
0.352\end{array}$ & $\begin{array}{l}0.848^{*} \\
0.371\end{array}$ & $\begin{array}{l}0.805^{* * *} \\
0.300\end{array}$ & $\begin{array}{l}0.803^{* *} \\
0.289\end{array}$ \\
\hline bank's loan market share prior calendar year & $\begin{array}{c}-0.525 \\
0.380\end{array}$ & $\begin{array}{c}-1.278^{* * *} \\
0.401\end{array}$ & $\begin{array}{l}1.025 \\
0.463\end{array}$ & $\begin{array}{c}-0.082 \\
0.446\end{array}$ \\
\hline
\end{tabular}


Table 4. Analyst Behavior (continued).

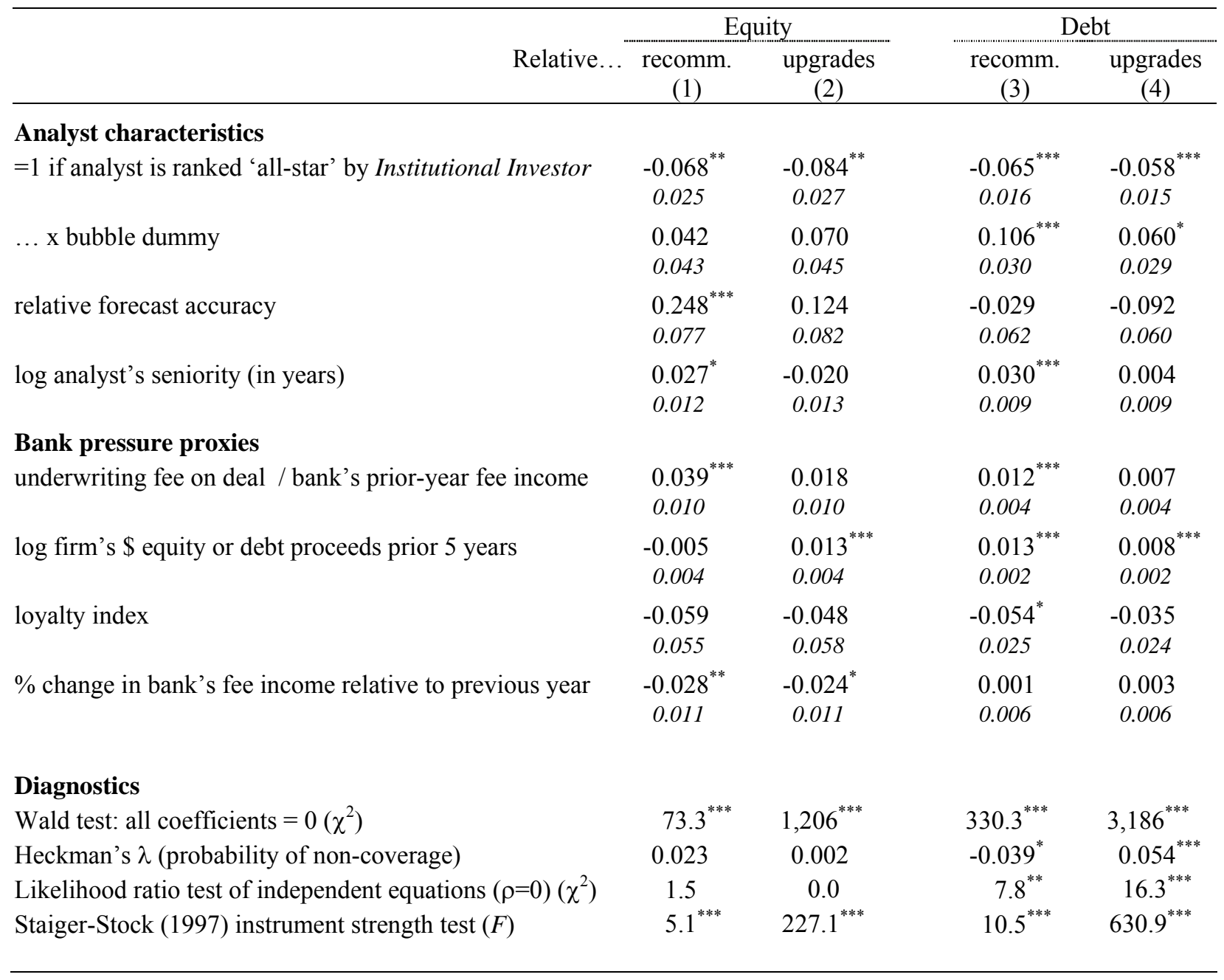


Table 5. Co-manager Choice, Equity Transactions.

In Model 1, we estimate the probability that a particular bank is chosen to co-manage a particular equity deal using probit MLE with sample selection correction as per Table 3. The first two columns use relative recommendations and relative upgrades to model analyst behavior, respectively, instrumented from the equations estimated in Table 4 and so treated as endogenous. Analyst behavior is observed only if the bank provides coverage, so column (3) estimates the probability of winning a mandate separately if the bank does not provide research coverage. Model 2 in column (4) pools the sample and estimates the effect of analyst coverage (irrespective of the level of recommendation) using a seemingly unrelated bivariate probit model which treats coverage as endogenous (see Greene, 2003, and Fabbri, Monfardini, and Radice, 2004). The first stage of the biprobit SUR model is illustrated in Table 3. The dummies for mergers are coded 1 in the quarter of the event, and $1 / 2,1 / 3$, and $1 / 4$ in the next three quarters. Intercepts are not shown. Standard errors are shown in italics. In the first two columns, they are based on the Murphy-Topel adjustment. In column (4), they are clustered on deal id and so heteroskedasticity-consistent. We use ${ }^{* * *},{ }^{* *}$, and ${ }^{*}$ to denote significance at the $0.1 \%, 1 \%$, and $5 \%$ level (two-sided), respectively. The number of covered and non-covered observations in the first three columns is 8,002 and 235,854 , respectively. The number of observations in column (4) is 244,624 .

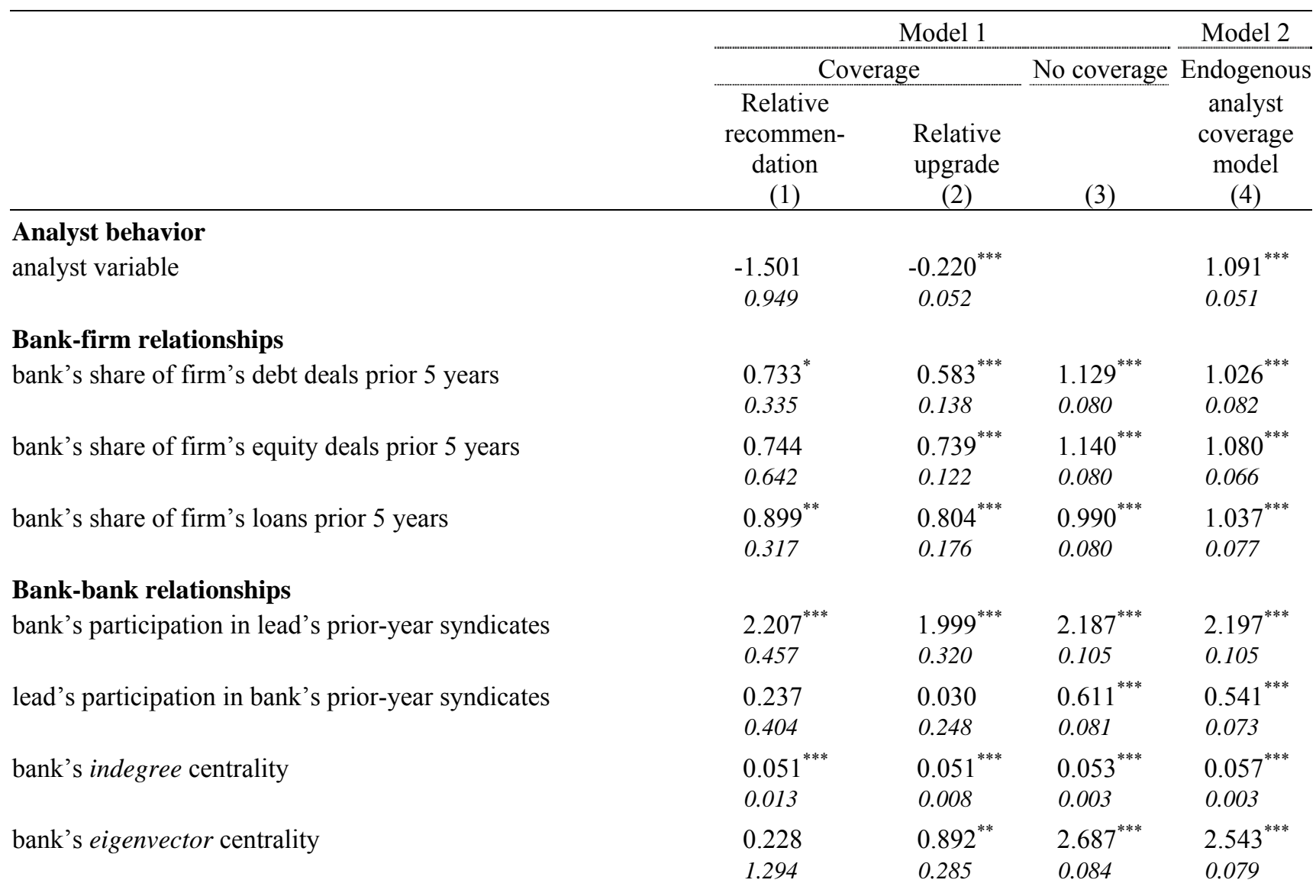


Table 5. Co-manager Choice, Equity Transactions (continued).

\begin{tabular}{|c|c|c|c|c|}
\hline & \multicolumn{3}{|c|}{ Model 1} & \multirow{3}{*}{$\begin{array}{c}\text { Model } 2 \\
\text { Endogenous } \\
\text { analyst } \\
\text { coverage } \\
\text { model } \\
(4)\end{array}$} \\
\hline & \multicolumn{2}{|c|}{ Coverage } & \multirow[b]{2}{*}{$\begin{array}{c}\text { No coverage } \\
\text { (3) }\end{array}$} & \\
\hline & $\begin{array}{l}\text { Relative } \\
\text { recommen- } \\
\text { dation } \\
(1)\end{array}$ & $\begin{array}{l}\text { Relative } \\
\text { upgrade } \\
\text { (2) }\end{array}$ & & \\
\hline \multicolumn{5}{|l|}{ Bank characteristics } \\
\hline bank's equity market share prior calendar year & $\begin{array}{r}-1.055 \\
1.359\end{array}$ & $\begin{array}{r}-0.357 \\
0.703\end{array}$ & $\begin{array}{r}-0.057 \\
0.304\end{array}$ & $\begin{array}{r}-0.052 \\
0.280\end{array}$ \\
\hline bank's debt market share prior calendar year & $\begin{array}{l}0.594 \\
0.995\end{array}$ & $\begin{array}{c}-0.280 \\
0.625\end{array}$ & $\begin{array}{r}-0.282 \\
0.266\end{array}$ & $\begin{array}{r}-0.311 \\
0.252\end{array}$ \\
\hline bank's loan market share prior calendar year & $\begin{array}{l}0.904 \\
0.959\end{array}$ & $\begin{array}{l}1.508^{*} \\
0.657\end{array}$ & $\begin{array}{l}2.308^{* * *} \\
0.242\end{array}$ & $\begin{array}{l}2.334^{* * *} \\
0.235\end{array}$ \\
\hline abs(lead's equity market share - bank's equity market share) & $\begin{array}{l}-4.869^{* * *} \\
1.325\end{array}$ & $\begin{array}{l}-4.140^{* * *} \\
0.967\end{array}$ & $\begin{array}{l}-6.356^{* * *} \\
0.393\end{array}$ & $\begin{array}{l}-6.169^{* * *} \\
0.406\end{array}$ \\
\hline$\ldots \mathrm{x}$ (lead is Top 10 bank) & $\begin{array}{l}3.070^{*} \\
1.266\end{array}$ & $\begin{array}{l}2.015^{*} \\
0.937\end{array}$ & $\begin{array}{l}5.798^{* * *} \\
0.372\end{array}$ & $\begin{array}{l}5.431^{* * *} \\
0.380\end{array}$ \\
\hline$=1$ if bank involved in merger & $\begin{array}{c}-0.084 \\
0.192\end{array}$ & $\begin{array}{l}0.042 \\
0.077\end{array}$ & $\begin{array}{l}0.241^{* * *} \\
0.029\end{array}$ & $\begin{array}{l}0.233^{* * *} \\
0.027\end{array}$ \\
\hline \multicolumn{5}{|l|}{ Analyst characteristics } \\
\hline$=1$ if analyst is ranked 'all-star' by Institutional Investor & $\begin{array}{l}0.010 \\
0.125\end{array}$ & $\begin{array}{l}0.090^{*} \\
0.043\end{array}$ & $\begin{array}{l}0.066^{* * *} \\
0.015\end{array}$ & $\begin{array}{l}1.091^{* * *} \\
0.051\end{array}$ \\
\hline log analyst's seniority (in years) & $\begin{array}{l}0.104^{* *} \\
0.038\end{array}$ & $\begin{array}{l}0.054^{*} \\
0.023\end{array}$ & & \\
\hline relative forecast accuracy & $\begin{array}{l}0.537 \\
0.303\end{array}$ & $\begin{array}{l}0.178 \\
0.140\end{array}$ & & \\
\hline \multicolumn{5}{|l|}{ Diagnostics } \\
\hline Pseudo $R^{2}$ & $19.3 \%$ & $22.6 \%$ & $18.9 \%$ & $23.1 \%$ \\
\hline Wald test: all coefficients $=0\left(\chi^{2}\right)$ & $415.7^{* * *}$ & $433.3^{* * *}$ & $4,737^{* * *}$ & $15,045^{* * *}$ \\
\hline Correlation of coverage and co-manager equations $(\rho)$ & $0.207^{* * *}$ & $0.228^{* * *}$ & $0.333^{* * *}$ & $0.132^{* * *}$ \\
\hline Likelihood ratio test of independent equations $(\rho=0)\left(\chi^{2}\right)$ & $38.5^{* * *}$ & $50.5^{* * *}$ & $63.6^{* * *}$ & $26.9^{* * *}$ \\
\hline
\end{tabular}


Table 6. Co-manager Choice, Debt Transactions.

In Model 1, we estimate the probability that a particular bank is chosen to co-manage a particular debt deal using probit MLE with sample selection correction as per Table 3. The first two columns use relative recommendations and relative upgrades to model analyst behavior, respectively, instrumented from the equations estimated in Table 4 and so treated as endogenous. Analyst behavior is observed only if the bank provides coverage, so column (3) estimates the probability of winning a mandate separately if the bank does not provide research coverage. Model 2 in column (4) pools the sample and estimates the effect of analyst coverage (irrespective of the level of recommendation) using a seemingly unrelated bivariate probit model which treats coverage as endogenous (see Greene, 2003, and Fabbri, Monfardini, and Radice, 2004). The first stage of the biprobit SUR model is illustrated in Table 3. The dummies for mergers are coded 1 in the quarter of the event, and $1 / 2,1 / 3$, and $1 / 4$ in the next three quarters. Intercepts are not shown. Standard errors are shown in italics. In the first two columns, they are based on the Murphy-Topel adjustment. In column (4), they are clustered on deal id and so heteroskedasticity-consistent. We use ${ }^{* * *},{ }^{* *}$, and ${ }^{*}$ to denote significance at the $0.1 \%, 1 \%$, and $5 \%$ level (two-sided), respectively. The number of covered and non-covered observations in the first three columns is 18,796 and 149,900 , respectively. The number of observations in column (4) is 170,136.

\begin{tabular}{|c|c|c|c|c|}
\hline & & Model 1 & & Model 2 \\
\hline & & & No coverage & Endogenous \\
\hline & $\begin{array}{l}\text { Relative } \\
\text { recommen- } \\
\text { dation } \\
(1)\end{array}$ & $\begin{array}{l}\text { Relative } \\
\text { upgrade } \\
\text { (2) }\end{array}$ & $(3)$ & $\begin{array}{c}\text { analyst } \\
\text { coverage } \\
\text { model } \\
(4)\end{array}$ \\
\hline $\begin{array}{l}\text { Analyst behavior } \\
\text { analyst variable }\end{array}$ & $\begin{array}{l}1.632^{* * *} \\
0.477\end{array}$ & $\begin{array}{c}-0.083^{*} \\
0.037\end{array}$ & & $\begin{array}{l}0.313^{* * *} \\
0.034\end{array}$ \\
\hline $\begin{array}{l}\text { Bank-firm relationships } \\
\text { bank's share of firm's debt deals prior } 5 \text { years }\end{array}$ & $\begin{array}{l}0.500^{*} \\
0.246\end{array}$ & $\begin{array}{l}1.086^{* * *} \\
0.084\end{array}$ & $\begin{array}{l}1.091^{* * *} \\
0.064\end{array}$ & $\begin{array}{l}1.079^{* * *} \\
0.058\end{array}$ \\
\hline bank's share of firm's equity deals prior 5 years & $\begin{array}{l}0.335^{*} \\
0.155\end{array}$ & $\begin{array}{l}0.623^{* * *} \\
0.069\end{array}$ & $\begin{array}{l}0.379^{* * *} \\
0.067\end{array}$ & $\begin{array}{l}0.490^{* * *} \\
0.052\end{array}$ \\
\hline bank's share of firm's loans prior 5 years & $\begin{array}{l}1.065^{* * *} \\
0.271\end{array}$ & $\begin{array}{l}1.768^{* * *} \\
0.149\end{array}$ & $\begin{array}{l}1.333^{* * *} \\
0.054\end{array}$ & $\begin{array}{l}1.378^{* * *} \\
0.058\end{array}$ \\
\hline $\begin{array}{l}\text { Bank-bank relationships } \\
\text { bank's participation in lead's prior-year syndicates }\end{array}$ & $\begin{array}{l}2.508^{* * *} \\
0.375\end{array}$ & $\begin{array}{l}2.672^{* * *} \\
0.278\end{array}$ & $\begin{array}{l}2.356^{* * *} \\
0.127\end{array}$ & $\begin{array}{l}2.440^{* * *} \\
0.132\end{array}$ \\
\hline lead's participation in bank's prior-year syndicates & $\begin{array}{r}-0.035 \\
0.229\end{array}$ & $\begin{array}{l}0.087 \\
0.182\end{array}$ & $\begin{array}{l}0.206^{*} \\
0.086\end{array}$ & $\begin{array}{l}0.202^{* *} \\
0.078\end{array}$ \\
\hline bank's indegree centrality & $\begin{array}{l}0.061^{* * *} \\
0.009\end{array}$ & $\begin{array}{l}0.039^{* * *} \\
0.006\end{array}$ & $\begin{array}{l}0.093^{* * *} \\
0.003\end{array}$ & $\begin{array}{l}0.083^{* * *} \\
0.003\end{array}$ \\
\hline bank's eigenvector centrality & $\begin{array}{l}1.555^{*} \\
0.647\end{array}$ & $\begin{array}{l}2.307^{* * *} \\
0.208\end{array}$ & $\begin{array}{l}3.143^{* * *} \\
0.087\end{array}$ & $\begin{array}{l}3.171^{* * *} \\
0.084\end{array}$ \\
\hline
\end{tabular}


Table 6. Co-manager Choice, Debt Transactions (continued).

\begin{tabular}{|c|c|c|c|c|}
\hline & \multicolumn{3}{|c|}{ Model 1} & \multirow{3}{*}{$\begin{array}{c}\text { Model } 2 \\
\text { Endogenous } \\
\text { analyst } \\
\text { coverage } \\
\text { model } \\
(4) \\
\end{array}$} \\
\hline & \multicolumn{2}{|c|}{ Coverage } & \multirow{2}{*}{$\begin{array}{c}\text { No coverage } \\
\text { (3) }\end{array}$} & \\
\hline & $\begin{array}{l}\text { Relative } \\
\text { recommen- } \\
\text { dation } \\
\text { (1) }\end{array}$ & $\begin{array}{l}\text { Relative } \\
\text { upgrade } \\
\text { (2) }\end{array}$ & & \\
\hline \multicolumn{5}{|l|}{ Bank characteristics } \\
\hline bank's equity market share prior calendar year & $\begin{array}{l}1.211 \\
0.694\end{array}$ & $\begin{array}{c}-0.680 \\
0.416\end{array}$ & $\begin{array}{l}-1.132^{* * *} \\
0.269\end{array}$ & $\begin{array}{l}-0.980^{* * *} \\
0.236\end{array}$ \\
\hline bank's debt market share prior calendar year & $\begin{array}{r}-0.234 \\
0.784\end{array}$ & $\begin{array}{l}1.095^{*} \\
0.552\end{array}$ & $\begin{array}{l}2.788^{* * *} \\
0.327\end{array}$ & $\begin{array}{l}2.189^{* * *} \\
0.281\end{array}$ \\
\hline bank's loan market share prior calendar year & $\begin{array}{l}0.475 \\
1.244\end{array}$ & $\begin{array}{l}1.953^{*} \\
0.829\end{array}$ & $\begin{array}{l}2.564^{* * *} \\
0.273\end{array}$ & $\begin{array}{l}2.537^{* * *} \\
0.260\end{array}$ \\
\hline abs(lead's debt market share - bank's debt market share) & $\begin{array}{l}-6.875^{* * *} \\
0.897\end{array}$ & $\begin{array}{l}-6.390^{* * *} \\
0.675\end{array}$ & $\begin{array}{l}-5.589^{* * *} \\
0.447\end{array}$ & $\begin{array}{l}-6.176^{* * *} \\
0.498\end{array}$ \\
\hline$\ldots \mathrm{x}$ (lead is Top 10 bank) & $\begin{array}{l}5.901^{* * *} \\
0.953\end{array}$ & $\begin{array}{l}6.588^{* * *} \\
0.660\end{array}$ & $\begin{array}{l}5.854^{* * *} \\
0.435\end{array}$ & $\begin{array}{l}6.486^{* * *} \\
0.487\end{array}$ \\
\hline$=1$ if bank involved in merger & $\begin{array}{l}0.252^{* * *} \\
0.079\end{array}$ & $\begin{array}{l}0.203^{* * *} \\
0.061\end{array}$ & $\begin{array}{l}0.084^{* *} \\
0.029\end{array}$ & $\begin{array}{l}0.111^{* * *} \\
0.027\end{array}$ \\
\hline \multicolumn{5}{|l|}{ Analyst characteristics } \\
\hline$=1$ if analyst is ranked 'all-star' by Institutional Investor & $\begin{array}{l}0.119^{* *} \\
0.041\end{array}$ & $\begin{array}{l}0.046 \\
0.029\end{array}$ & $\begin{array}{l}-0.100^{* * *} \\
0.019\end{array}$ & $\begin{array}{c}-0.044^{*} \\
0.017\end{array}$ \\
\hline log analyst's seniority (in years) & $\begin{array}{c}-0.052 \\
0.036\end{array}$ & $\begin{array}{r}-0.002 \\
0.020\end{array}$ & & \\
\hline relative forecast accuracy & $\begin{array}{l}0.528^{* * *} \\
0.163\end{array}$ & $\begin{array}{l}0.493^{* * *} \\
0.133\end{array}$ & & \\
\hline \multicolumn{5}{|l|}{ Diagnostics } \\
\hline Pseudo $R^{2}$ & $26.1 \%$ & $26.1 \%$ & $25.2 \%$ & $24.6 \%$ \\
\hline Wald test: all coefficients $=0\left(\chi^{2}\right)$ & $1,499^{* * *}$ & $1,495^{* * *}$ & $8,209^{* * *}$ & $24,769^{* * *}$ \\
\hline Correlation of coverage and co-manager equations $(\rho)$ & $0.060^{* *}$ & $0.087^{* *}$ & $0.290^{* * *}$ & $-0.080^{* * *}$ \\
\hline Likelihood ratio test of independent equations $(\rho=0)\left(\chi^{2}\right)$ & $4.0^{*}$ & $8.6^{* *}$ & $113.8^{* * *}$ & $16.6^{* * *}$ \\
\hline
\end{tabular}


Table 7. Co-manager Choice, Various Sample Splits.

As in Tables 5 and 6, we estimate the probability that a particular bank is chosen to co-manage a particular deal treating the analyst's recommendation behavior as endogenous (Model 1). In the interest of brevity, we only report the coefficients estimated for the analyst recommendation upgrade. The effect of the other covariates can be seen in Tables 8 through 11, which report complete results for the same sample splits using Model 2. Intercepts are not shown. Standard errors (which are clustered on deal id) are shown in italics. We use ${ }^{* * *},{ }^{* *}$, and ${ }^{*}$ to denote significance at the $0.1 \%, 1 \%$, and $5 \%$ level (two-sided), respectively.

\begin{tabular}{|c|c|c|}
\hline & \multicolumn{2}{|c|}{$\begin{array}{l}\text { Effect of relative upgrades } \\
\text { on } \operatorname{Pr} \text { (becoming co- } \\
\text { manager) }\end{array}$} \\
\hline & $\begin{array}{c}\text { Equity } \\
\text { (1) }\end{array}$ & $\begin{array}{c}\text { Debt } \\
(2)\end{array}$ \\
\hline \multicolumn{3}{|l|}{ Sample split by deal year } \\
\hline 1993-1997 & $\begin{array}{l}-0.425^{* * *} \\
0.084\end{array}$ & $\begin{array}{c}-0.121^{*} \\
0.058\end{array}$ \\
\hline $1998-2002$ & $\begin{array}{r}-0.072 \\
0.064\end{array}$ & $\begin{array}{c}-0.086 \\
0.049\end{array}$ \\
\hline \multicolumn{3}{|l|}{ Sample split by deal size } \\
\hline$<\$ 100$ million & $\begin{array}{c}-0.229^{* *} \\
0.089\end{array}$ & $\begin{array}{c}-0.109 \\
0.105\end{array}$ \\
\hline$\geq \$ 100$ million & $\begin{array}{l}-0.227^{* * *} \\
0.063\end{array}$ & $\begin{array}{c}-0.086^{*} \\
0.040\end{array}$ \\
\hline \multicolumn{3}{|l|}{ Sample split by lead manager type } \\
\hline lead manager is investment bank & $\begin{array}{l}-0.313^{* * *} \\
0.058\end{array}$ & $\begin{array}{c}-0.040 \\
0.043\end{array}$ \\
\hline lead manager is commercial bank & $\begin{array}{l}0.312^{*} \\
0.132\end{array}$ & $\begin{array}{l}-0.240^{* * *} \\
0.071\end{array}$ \\
\hline \multicolumn{3}{|l|}{ Sample split by lead manager coverage } \\
\hline lead manager covers issuer's stock & $\begin{array}{c}-0.176^{* *} \\
0.060\end{array}$ & $\begin{array}{c}-0.075 \\
0.045\end{array}$ \\
\hline lead manager does not cover issuer's stock & $\begin{array}{c}-0.325^{* * *} \\
0.098\end{array}$ & $\begin{array}{c}-0.099 \\
0.067\end{array}$ \\
\hline
\end{tabular}


Table 8. Co-manager Choice, 1993-1997 versus 1998-2002.

As in Tables 5 and 6, we estimate the probability that a particular bank is chosen to co-manage a particular deal treating the decision whether or not to provide coverage as endogenous (Model 2). We split the sample into two sub-samples by deal year. Intercepts are not shown. Standard errors (which are clustered on deal id) are shown in italics. We use ${ }^{* * * * *}$, and ${ }^{*}$ to denote significance at the $0.1 \%, 1 \%$, and $5 \%$ level (two-sided), respectively.

\begin{tabular}{|c|c|c|c|c|}
\hline & \multicolumn{2}{|c|}{ Equity } & \multicolumn{2}{|c|}{ Debt } \\
\hline & $\begin{array}{c}1993-1997 \\
(1)\end{array}$ & $\begin{array}{c}1998-2002 \\
(2)\end{array}$ & $\begin{array}{c}1993-1997 \\
(3)\end{array}$ & $\begin{array}{c}1998-2002 \\
(4)\end{array}$ \\
\hline $\begin{array}{l}\text { Research coverage } \\
\text { candidate bank provides coverage }\end{array}$ & $\begin{array}{l}0.941^{* * *} \\
0.067\end{array}$ & $\begin{array}{l}1.252^{* * *} \\
0.069\end{array}$ & $\begin{array}{l}0.315^{* * *} \\
0.056\end{array}$ & $\begin{array}{l}0.262^{* * *} \\
0.045\end{array}$ \\
\hline $\begin{array}{l}\text { Bank-firm relationships } \\
\text { bank's share of firm's debt deals prior } 5 \text { years }\end{array}$ & $\begin{array}{l}1.147^{* * *} \\
0.116\end{array}$ & $\begin{array}{l}0.862^{* * *} \\
0.116\end{array}$ & $\begin{array}{l}1.485^{* * *} \\
0.088\end{array}$ & $\begin{array}{l}0.723^{* * *} \\
0.078\end{array}$ \\
\hline bank's share of firm's equity deals prior 5 years & $\begin{array}{l}1.441^{* * *} \\
0.091\end{array}$ & $\begin{array}{l}0.675^{* * *} \\
0.092\end{array}$ & $\begin{array}{l}0.791^{* * *} \\
0.073\end{array}$ & $\begin{array}{l}0.158^{*} \\
0.075\end{array}$ \\
\hline bank's share of firm's loans prior 5 years & $\begin{array}{l}1.422^{* * *} \\
0.152\end{array}$ & $\begin{array}{l}0.861^{* * *} \\
0.088\end{array}$ & $\begin{array}{l}1.577^{* * *} \\
0.089\end{array}$ & $\begin{array}{l}1.343^{* * *} \\
0.080\end{array}$ \\
\hline $\begin{array}{l}\text { Bank-bank relationships } \\
\text { bank's participation in lead's prior-year syndicates }\end{array}$ & $\begin{array}{l}2.138^{* * *} \\
0.124\end{array}$ & $\begin{array}{l}2.287^{* * *} \\
0.194\end{array}$ & $\begin{array}{l}1.721^{* * *} \\
0.166\end{array}$ & $\begin{array}{l}3.378^{* * *} \\
0.267\end{array}$ \\
\hline lead's participation in bank's prior-year syndicates & $\begin{array}{l}0.721^{* * *} \\
0.088\end{array}$ & $\begin{array}{l}0.196 \\
0.131\end{array}$ & $\begin{array}{l}0.540^{* * *} \\
0.097\end{array}$ & $\begin{array}{l}0.059 \\
0.126\end{array}$ \\
\hline bank's indegree centrality & $\begin{array}{l}0.044^{* * *} \\
0.005\end{array}$ & $\begin{array}{l}0.034^{* * *} \\
0.005\end{array}$ & $\begin{array}{l}0.051^{* * *} \\
0.006\end{array}$ & $\begin{array}{l}0.063^{* * *} \\
0.004\end{array}$ \\
\hline bank's eigenvector centrality & $\begin{array}{l}2.165^{* * *} \\
0.106\end{array}$ & $\begin{array}{l}3.182^{* * *} \\
0.125\end{array}$ & $\begin{array}{l}2.943^{* * *} \\
0.130\end{array}$ & $\begin{array}{l}3.576^{* * *} \\
0.119\end{array}$ \\
\hline $\begin{array}{l}\text { Bank characteristics } \\
\text { bank's equity market share prior calendar year }\end{array}$ & $\begin{array}{l}1.640^{* * *} \\
0.414\end{array}$ & $\begin{array}{l}-2.356^{* * *} \\
0.400\end{array}$ & $\begin{array}{c}-0.971^{*} \\
0.425\end{array}$ & $\begin{array}{c}-0.868^{* *} \\
0.311\end{array}$ \\
\hline bank's debt market share prior calendar year & $\begin{array}{c}-1.238^{* *} \\
0.391\end{array}$ & $\begin{array}{l}0.149 \\
0.336\end{array}$ & $\begin{array}{l}1.770^{* * *} \\
0.520\end{array}$ & $\begin{array}{l}1.872 \\
0.361\end{array}$ \\
\hline bank's loan market share prior calendar year & $\begin{array}{l}6.727^{* * *} \\
1.077\end{array}$ & $\begin{array}{l}2.133^{* * *} \\
0.248\end{array}$ & $\begin{array}{l}2.605^{* * *} \\
0.499\end{array}$ & $\begin{array}{l}2.448^{* * *} \\
0.316\end{array}$ \\
\hline abs(lead's market share - bank's market share) & $\begin{array}{c}-5.414^{* * *} \\
0.511\end{array}$ & $\begin{array}{l}-7.401^{* *} \\
0.632\end{array}$ & $\begin{array}{c}-2.640^{* * *} \\
0.541\end{array}$ & $\begin{array}{c}-10.294^{* * *} \\
1.069\end{array}$ \\
\hline$\ldots \mathrm{x}$ (lead is Top 10 bank) & $\begin{array}{l}4.801^{* * *} \\
0.471\end{array}$ & $\begin{array}{l}6.319^{* * *} \\
0.597\end{array}$ & $\begin{array}{l}2.005^{* * *} \\
0.488\end{array}$ & $\begin{array}{c}10.816^{* * *} \\
1.050\end{array}$ \\
\hline$=1$ if bank involved in merger & $\begin{array}{l}0.008 \\
0.062\end{array}$ & $\begin{array}{l}0.208^{* * *} \\
0.032\end{array}$ & $\begin{array}{l}0.139^{* * *} \\
0.053\end{array}$ & $\begin{array}{l}0.070^{*} \\
0.031\end{array}$ \\
\hline $\begin{array}{l}\text { Analyst characteristics } \\
=1 \text { if bank has all-star analyst covering issuer's industry }\end{array}$ & $\begin{array}{l}0.084 \\
0.046\end{array}$ & $\begin{array}{l}0.141^{* * *} \\
0.022\end{array}$ & $\begin{array}{l}0.040 \\
0.028\end{array}$ & $\begin{array}{l}-0.123^{* * *} \\
0.023\end{array}$ \\
\hline Diagnostics & & & & \\
\hline $\begin{array}{l}\text { Pseudo } R^{2} \\
\text { Wald test: all coefficients }=0\left(\chi^{2}\right)\end{array}$ & $\begin{array}{r}22.6 \% \\
6,557^{* * *}\end{array}$ & $\begin{array}{r}23.5 \% \\
9,180^{* * *}\end{array}$ & $\begin{array}{r}28.0 \% \\
11,629^{* * *}\end{array}$ & $\begin{array}{r}22.4 \% \\
15,856^{* * *}\end{array}$ \\
\hline Correlation of coverage and co-manager equations $(\rho)$ & $0.214^{* * *}$ & 0.048 & 0.018 & $-0.105^{* * *}$ \\
\hline Likelihood ratio test of independent equations $(\rho=0)\left(\chi^{2}\right)$ & $39.4^{* * *}$ & 1.8 & 0.3 & $17.2^{* * *}$ \\
\hline
\end{tabular}


Table 9. Co-manager Choice, Small versus Large Transactions.

As in Tables 5 and 6 , we estimate the probability that a particular bank is chosen to co-manage a particular deal treating the decision whether or not to provide coverage as endogenous (Model 2). We split the sample into two sub-samples by deal size. Small deals raise less than $\$ 100$ million. Intercepts are not shown. Standard errors (which are clustered on deal id) are shown in italics. We use ${ }^{* * *},{ }^{* *}$, and ${ }^{*}$ to denote significance at the $0.1 \%, 1 \%$, and $5 \%$ level (two-sided), respectively.

\begin{tabular}{ccccc}
\multicolumn{2}{c}{ Equity } & & \multicolumn{2}{c}{ Debt } \\
\cline { 1 - 1 } Small deal & Large deal & & Small deal & Large deal \\
$(1)$ & $(2)$ & & $(3)$ & $(4)$
\end{tabular}

\section{Research coverage}

candidate bank provides coverage

\section{Bank-firm relationships}

bank's share of firm's debt deals prior 5 years

bank's share of firm's equity deals prior 5 years

bank's share of firm's loans prior 5 years

\section{Bank-bank relationships}

bank's participation in lead's prior-year syndicates

lead's participation in bank's prior-year syndicates

bank's indegree centrality

bank's eigenvector centrality

\section{Bank characteristics}

bank's equity market share prior calendar year

bank's debt market share prior calendar year

bank's loan market share prior calendar year

abs(lead's market share - bank's market share)

... $\mathrm{x}$ (lead is Top 10 bank)

$=1$ if bank involved in merger

\section{Analyst characteristics}

$=1$ if bank has all-star analyst covering issuer's industry

\section{Diagnostics}

Pseudo $R^{2}$

Wald test: all coefficients $=0\left(\chi^{2}\right)$

Correlation of coverage and co-manager equations $(\rho)$

Likelihood ratio test of independent equations $(\rho=0)\left(\chi^{2}\right)$

$0.854^{* * *}$

0.078

$0.851^{* * *}$

0.120

$1.280^{* * *}$

0.088

$0.730^{* * *}$

0.117

$1.947^{* *}$

0.121

$0.509^{* * *}$

0.091

$0.059^{* * *}$

0.004

$2.630^{* * *}$

0.101

$-0.826$

0.431

$-3.233^{* * *}$

0.380

$3.015^{* * *}$

0.336

$-4.547^{* * *}$

0.540

$4.089^{* * *}$

0.501

$0.265^{* * *}$

0.035

$0.038^{*}$

0.019

$20.9 \%$

$7,229^{* * *}$

$0.308^{* * *}$

$63.0^{* * *}$

$0.873^{* * *}$

0.070

$1.159^{* * *}$

0.115

$1.020^{* * *}$

0.100

$1.273^{* * *}$

0.113

$2.346^{* * *}$

0.214

$0.421^{* * *}$

0.129

$0.042^{* * *}$

0.005

$2.975^{* * *}$

0.132

$-0.369$

0.402

$1.833^{* * *}$

0.362

$1.856^{* * *}$

0.332

$-3.768^{* * *}$

0.601

$2.898^{* * *}$

0.567

$0.230^{* * *}$

0.043

$0.154^{* * *}$

0.025

$24.2 \%$

$7,948^{* * *}$

$0.169^{* * *}$

$20.4^{* * *}$
$0.473^{* * *}$

$0.178^{* * *}$

0.043

$0.786^{* * *}$

$1.179^{* * *}$

0.068

$0.575^{* * *}$

0.061

$1.667^{* * *}$

0.071

0.138

$2.072^{* * *}$

0.148

0.163

0.091

$0.098^{* * *}$

0.003

$3.922^{* * *}$

0.093

0.159

0.882

$-1.418^{* * *}$

0.272

$1.508^{* * *}$

$4.463^{* * *}$

0.333

0.540

$2.203^{* * *}$

0.297

3.784
0.580

$-3.706^{* * *}$

0.603

0.748

$3.460^{* * *}$

0.575

$0.140^{* * *}$

0.031

0.037

$0.094^{* *}$

$-0.049^{*}$

0.020

.034

$25.1 \%$

$10,826^{* * *}$

$25.3 \%$

$18,440^{* * *}$

$-0.286^{* * *}$

0.030

1.5 
Table 10. Transactions Lead-managed by Investment Banks versus Commercial Banks.

As in Tables 5 and 6, we estimate the probability that a particular bank is chosen to co-manage a particular deal treating the decision whether to provide coverage as endogenous (Model 2). We split the sample into two sub-samples by the lead manager's status as commercial or investment bank. Intercepts are not shown. Standard errors (which are clustered on deal id) are shown in italics. We use ${ }^{* * *},{ }^{* *}$, and ${ }^{*}$ to denote significance at the $0.1 \%, 1 \%$, and $5 \%$ level (two-sided), respectively.

\begin{tabular}{ccccc}
\multicolumn{3}{c}{ Equity } & \multicolumn{2}{c}{ Debt } \\
${$\cline { 5 - 5 }$} }$ & Lead is CB & Lead is IB & Lead is CB \\
$(1)$ & (2) & & (3) & (4)
\end{tabular}

\section{Research coverage}

candidate bank provides coverage

\section{Bank-firm relationships}

bank's share of firm's debt deals prior 5 years

bank's share of firm's equity deals prior 5 years

bank's share of firm's loans prior 5 years

$\begin{array}{llll}1.075^{* * *} & 1.215^{* * *} & 0.341^{* * *} & -0.142 \\ 0.054 & 0.147 & 0.040 & 0.076\end{array}$

\section{Bank-bank relationships}

bank's participation in lead's prior-year syndicates

lead's participation in bank's prior-year syndicates

bank's indegree centrality

bank's eigenvector centrality

\section{Bank characteristics}

bank's equity market share prior calendar year

$0.983^{* * *}$

0.088

$1.333^{* * *}$

$1.125^{* * *}$

$0.953^{* * *}$

$1.099^{* * *}$

0.216

0.069

0.112

0.071

$0.940^{* * *}$

$0.548^{* * *}$

$0.566^{* * *}$

$1.109^{* * *}$

0.171

0.087

$0.713^{* * *}$

0.173

0.061

0.102

$2.176^{*}$

0.113

$0.517^{* * *}$

0.080

$0.052^{* * *}$

0.003

$2.488^{* * *}$

0.086

$2.213^{* * *}$

0.274

$0.508^{* *}$

0.198

$1.372^{* * *}$

$1.572^{* * *}$

0.147

bank's debt market share prior calendar year

bank's loan market share prior calendar year

abs(lead's market share - bank's market share)

... $\mathrm{x}$ (lead is Top 10 bank)

$=1$ if bank involved in merger

\section{Analyst characteristics}

$=1$ if bank has all-star analyst covering issuer's industry

$$
0.085^{* * *}
$$

$0.075^{* * *}$

0.008

$2.945^{* * *}$

0.209

$2.601^{* * *}$

$1.173^{* * *}$

0.209

$0.829^{* * *}$

0.181

0.087

$0.074^{* * *}$

$0.088^{* * *}$

0.006

0.003

$3.767^{* * *}$

$2.948^{* * *}$

0.179

\subsection{7}

$-2.027^{* *}$

0.091

$-0.308$

0.776

0.059

$-0.919$

0.277

0.439

$2.568^{* * *}$

0.272

0.627

$-7.148^{* * *}$

$1.804^{* * *}$

0.484

0.530

$-3.524^{* * *}$

$6.523^{* * *}$

0.844

0.502

$2.337^{* * *}$

0.737

$0.215^{* * *}$

$0.268^{* * *}$

0.057

0.269

0.507

$1.759^{* * *}$

$1.485^{* * *}$

0.273

0.538

$3.010^{* * *}$

$2.969^{* * *}$

0.345

0.609

$-4.470^{* * *}$

$-5.887^{* * *}$

0.610

0.776

$4.148^{* * *}$

$7.789^{* * *}$

0.583

0.760

$0.099^{* * *}$

$0.137^{*}$

0.057

\section{Diagnostics}

Pseudo $R^{2}$

Wald test: all coefficients $=0\left(\chi^{2}\right)$

Correlation of coverage and co-manager equations $(\rho)$

Likelihood ratio test of independent equations $(\rho=0)\left(\chi^{2}\right)$

0.060

0.037

$-0.026$

0.019

$-0.081^{*}$

0.040

$22.1 \%$
$2,706^{* * *}$
$0.162^{*}$
$5.3^{*}$

$24.8 \%$
$20,775^{* * *}$
$-0.082^{* * *}$
$12.8^{* * *}$

$26.4 \%$ $5,657^{* * *}$

$0.192^{* * *}$

$18.6^{* * *}$ 
Table 11. Co-manager Choice, Split by Lead Manager Coverage

As in Tables 5 and 6, we estimate the probability that a particular bank is chosen to co-manage a particular deal treating the decision whether or not to provide coverage as endogenous (Model 2). We split the sample according to whether the lead manager provides coverage for the issuer's stock. Intercepts are not shown. Standard errors (which are clustered on deal id) are shown in italics. We use ${ }^{* * *},{ }^{* *}$, and ${ }^{*}$ to denote significance at the $0.1 \%, 1 \%$, and $5 \%$ level (two-sided), respectively.

\begin{tabular}{|c|c|c|c|c|}
\hline & \multicolumn{2}{|c|}{ Equity } & \multicolumn{2}{|c|}{ Debt } \\
\hline & $\begin{array}{l}\text { Coverage } \\
(1)\end{array}$ & $\begin{array}{c}\text { No cov. } \\
(2)\end{array}$ & $\begin{array}{l}\text { Coverage } \\
(3)\end{array}$ & $\begin{array}{c}\text { No cov. } \\
(4)\end{array}$ \\
\hline $\begin{array}{l}\text { Research coverage } \\
\text { candidate bank provides coverage }\end{array}$ & $\begin{array}{l}1.559^{* * *} \\
0.062\end{array}$ & $\begin{array}{l}0.954^{* * *} \\
0.081\end{array}$ & $\begin{array}{l}0.193^{* * *} \\
0.052\end{array}$ & $\begin{array}{l}0.125^{*} \\
0.060\end{array}$ \\
\hline $\begin{array}{l}\text { Bank-firm relationships } \\
\text { bank's share of firm's debt deals prior } 5 \text { years }\end{array}$ & $\begin{array}{l}0.830^{* * *} \\
0.137\end{array}$ & $\begin{array}{l}1.111^{* * *} \\
0.102\end{array}$ & $\begin{array}{l}1.187^{* * *} \\
0.089\end{array}$ & $\begin{array}{l}1.072^{* * *} \\
0.077\end{array}$ \\
\hline bank's share of firm's equity deals prior 5 years & $\begin{array}{l}0.738^{* * *} \\
0.097\end{array}$ & $\begin{array}{l}1.302^{* * *} \\
0.090\end{array}$ & $\begin{array}{l}0.461^{* * *} \\
0.077\end{array}$ & $\begin{array}{l}0.585^{* * *} \\
0.071\end{array}$ \\
\hline bank's share of firm's loans prior 5 years & $\begin{array}{l}1.092^{* * *} \\
0.117\end{array}$ & $\begin{array}{l}1.011^{* * *} \\
0.107\end{array}$ & $\begin{array}{l}1.760^{* * *} \\
0.087\end{array}$ & $\begin{array}{l}1.104^{* * *} \\
0.081\end{array}$ \\
\hline \multicolumn{5}{|l|}{ Bank-bank relationships } \\
\hline bank's participation in lead's prior-year syndicates & $\begin{array}{l}2.563^{* * *} \\
0.218\end{array}$ & $\begin{array}{l}2.034^{* * *} \\
0.119\end{array}$ & $\begin{array}{l}2.849^{* * *} \\
0.227\end{array}$ & $\begin{array}{l}2.198^{* * *} \\
0.161\end{array}$ \\
\hline lead's participation in bank's prior-year syndicates & $\begin{array}{l}0.408^{* *} \\
0.138\end{array}$ & $\begin{array}{l}0.592^{* * *} \\
0.085\end{array}$ & $\begin{array}{r}-0.003 \\
0.131\end{array}$ & $\begin{array}{l}0.331^{* * *} \\
0.094\end{array}$ \\
\hline bank's indegree centrality & $\begin{array}{l}0.056^{* * *} \\
0.006\end{array}$ & $\begin{array}{l}0.062^{* * *} \\
0.003\end{array}$ & $\begin{array}{l}0.097^{* * *} \\
0.005\end{array}$ & $\begin{array}{l}0.076^{* * *} \\
0.004\end{array}$ \\
\hline bank's eigenvector centrality & $\begin{array}{l}1.993^{* * *} \\
0.148\end{array}$ & $\begin{array}{l}2.671^{* * *} \\
0.094\end{array}$ & $\begin{array}{l}3.657^{* * *} \\
0.128\end{array}$ & $\begin{array}{l}2.802^{* * *} \\
0.111\end{array}$ \\
\hline \multicolumn{5}{|l|}{ Bank characteristics } \\
\hline bank's equity market share prior calendar year & $\begin{array}{r}-0.003 \\
0.520\end{array}$ & $\begin{array}{l}0.037 \\
0.336\end{array}$ & $\begin{array}{c}-0.814^{*} \\
0.346\end{array}$ & $\begin{array}{c}-0.949^{* *} \\
0.324\end{array}$ \\
\hline bank's debt market share prior calendar year & $\begin{array}{l}1.148^{*} \\
0.464\end{array}$ & $\begin{array}{c}-0.828^{* *} \\
0.305\end{array}$ & $\begin{array}{l}1.187^{* *} \\
0.437\end{array}$ & $\begin{array}{l}3.054^{* * *} \\
0.377\end{array}$ \\
\hline bank's loan market share prior calendar year & $\begin{array}{l}1.760^{* * *} \\
0.431\end{array}$ & $\begin{array}{l}2.518^{* * *} \\
0.285\end{array}$ & $\begin{array}{l}2.143^{* * *} \\
0.403\end{array}$ & $\begin{array}{l}2.823^{* * *} \\
0.341\end{array}$ \\
\hline abs(lead's market share - bank's market share) & $\begin{array}{c}-4.416^{* * *} \\
0.661\end{array}$ & $\begin{array}{l}-6.983^{* * *} \\
0.528\end{array}$ & $\begin{array}{c}-9.156^{* * *} \\
1.002\end{array}$ & $\begin{array}{c}-4.997^{* * *} \\
0.549\end{array}$ \\
\hline$\ldots \mathrm{x}$ (lead is Top 10 bank) & $\begin{array}{l}3.061^{* * *} \\
0.621\end{array}$ & $\begin{array}{l}6.432^{* * *} \\
0.494\end{array}$ & $\begin{array}{l}9.813^{* * *} \\
0.999\end{array}$ & $\begin{array}{l}5.108^{* * *} \\
0.522\end{array}$ \\
\hline$=1$ if bank involved in merger & $\begin{array}{l}0.139^{* *} \\
0.052\end{array}$ & $\begin{array}{l}0.260^{* * *} \\
0.031\end{array}$ & $\begin{array}{l}0.175^{* * *} \\
0.041\end{array}$ & $\begin{array}{l}0.067 \\
0.035\end{array}$ \\
\hline \multicolumn{5}{|l|}{ Analyst characteristics } \\
\hline$=1$ if bank has all-star analyst covering issuer's industry & $\begin{array}{c}-0.033 \\
0.029\end{array}$ & $\begin{array}{l}0.099^{* * *} \\
0.017\end{array}$ & $\begin{array}{r}-0.042 \\
0.028\end{array}$ & $\begin{array}{l}0.028 \\
0.023\end{array}$ \\
\hline \multicolumn{5}{|l|}{ Diagnostics } \\
\hline Pseudo $R^{2}$ & $25.8 \%$ & $18.8 \%$ & $29.4 \%$ & $22.8 \%$ \\
\hline Wald test: all coefficients $=0\left(\chi^{2}\right)$ & $8,306^{* * *}$ & $7,792^{* * *}$ & $13,389^{* * *}$ & $12,630^{* * *}$ \\
\hline Correlation of coverage and co-manager equations $(\rho)$ & $0.036^{* *}$ & $0.109^{* *}$ & $0.066^{*}$ & -0.006 \\
\hline Likelihood ratio test of independent equations $(\rho=0)\left(\chi^{2}\right)$ & 1.2 & $9.2^{* *}$ & $4.5^{*}$ & 0.0 \\
\hline
\end{tabular}




\section{Table 12. Lead-manager Choice}

We estimate the probability that a given bank is chosen to lead-manage a particular securities transaction. The specification is similar to Model 2, except that the dependent variable equals 1 if the bank won the lead-management mandate, and 0 otherwise. As before, we concentrate on deals lead-managed by one of the 50 largest underwriters at the time and treat the 50 largest underwriters as being in competition for each deal. Note that we include deals that do not involve co-managers here. There are 6,073 equity deals and 11,056 debt deals in the sample, resulting in 303,650 observations in column (1) and 551,764 observations in column (3). In columns (2) and (4) we restrict the samples to the 1,851 equity and 1,704 debt deals in which the issuer had an exclusive lead-management relationship with one bank and treat the 50 largest underwriters as competing for each deal. The models are estimated using a seemingly unrelated bivariate probit model which treats coverage as endogenous. The first-stage models of the biprobit SUR look similar to those illustrated in Table 3 and are not reported. Intercepts are not shown. Heteroskedasticity-consistent standard errors (which are clustered on deal id) are shown in italics. We use ${ }^{* * *},{ }^{* *}$, and ${ }^{*}$ to denote significance at the $0.1 \%, 1 \%$, and $5 \%$ level (two-sided), respectively.

\begin{tabular}{|c|c|c|c|c|}
\hline & \multicolumn{2}{|c|}{ Equity } & \multicolumn{2}{|c|}{ Debt } \\
\hline & (1) & (2) & (3) & (4) \\
\hline \multicolumn{5}{|l|}{ Research coverage } \\
\hline \multirow[t]{2}{*}{ candidate bank provides coverage } & 0.011 & $0.534^{* * *}$ & $0.081^{* * *}$ & $0.175^{* * *}$ \\
\hline & 0.039 & 0.057 & 0.022 & 0.053 \\
\hline \multicolumn{5}{|l|}{ Bank-firm relationships (lead) } \\
\hline \multirow[t]{2}{*}{ bank's share of firm's debt deals as lead prior 5 years } & $1.059^{* * *}$ & $0.527^{* * *}$ & $1.941^{* * *}$ & $1.903^{* * *}$ \\
\hline & 0.060 & 0.111 & 0.027 & 0.044 \\
\hline \multirow[t]{2}{*}{ bank's share of firm's equity deals as lead prior 5 years } & $2.125^{* * *}$ & $2.208^{* * *}$ & $0.528^{* * *}$ & $0.399^{* * *}$ \\
\hline & 0.040 & 0.050 & 0.034 & 0.093 \\
\hline \multirow[t]{2}{*}{ bank's share of firm's loans as lead prior 5 years } & $0.837^{* * *}$ & $0.572^{* * *}$ & $1.232^{* * *}$ & $1.312^{* * *}$ \\
\hline & 0.071 & 0.153 & 0.034 & 0.081 \\
\hline \multicolumn{5}{|l|}{ Bank-firm relationships (co-manager) } \\
\hline \multirow[t]{2}{*}{ bank's share of firm's debt deals as co-manager prior 5 yrs } & $0.403^{* * *}$ & 0.072 & $1.516^{* * *}$ & $1.290^{* * *}$ \\
\hline & 0.127 & 0.220 & 0.052 & 0.092 \\
\hline \multirow[t]{2}{*}{ bank's share of firm's equity deals as co-manager prior 5 yrs } & $0.472^{* * *}$ & $0.852^{* * *}$ & $0.410^{* * *}$ & 0.131 \\
\hline & 0.060 & 0.077 & 0.063 & 0.175 \\
\hline \multicolumn{5}{|l|}{ Bank characteristics } \\
\hline \multirow[t]{2}{*}{ bank's equity market share prior calendar year } & $2.432^{* * *}$ & $2.195^{* * *}$ & $-1.754^{* * *}$ & $-2.484^{* * *}$ \\
\hline & 0.235 & 0.530 & 0.172 & 0.494 \\
\hline \multirow[t]{2}{*}{ bank's debt market share prior calendar year } & -0.410 & $1.269^{*}$ & $4.840^{* * *}$ & $5.968^{* * *}$ \\
\hline & 0.235 & 0.516 & 0.196 & 0.576 \\
\hline \multirow[t]{2}{*}{ bank's loan market share prior calendar year } & $2.042^{* * *}$ & 0.660 & $1.048^{* * *}$ & 0.835 \\
\hline & 0.248 & 0.671 & 0.167 & 0.476 \\
\hline \multirow[t]{2}{*}{ bank's indegree centrality } & $0.012^{* * *}$ & $0.020^{* * *}$ & $0.027^{* * *}$ & $0.028^{* * *}$ \\
\hline & 0.003 & 0.006 & 0.002 & 0.004 \\
\hline \multirow[t]{2}{*}{ bank's eigenvector centrality } & $2.750^{* * *}$ & $2.533^{* * *}$ & $1.573^{* * *}$ & $1.085^{* * *}$ \\
\hline & 0.092 & 0.204 & 0.060 & 0.165 \\
\hline \multirow[t]{2}{*}{$=1$ if bank involved in merger } & $0.126^{* * *}$ & 0.042 & $0.161^{* * *}$ & $0.208^{* * *}$ \\
\hline & 0.030 & 0.072 & 0.019 & 0.050 \\
\hline \multicolumn{5}{|l|}{ Analyst characteristics } \\
\hline \multirow[t]{2}{*}{$=1$ if bank has all-star analyst covering issuer's industry } & $0.142^{* * *}$ & 0.027 & 0.024 & -0.037 \\
\hline & 0.015 & 0.031 & 0.013 & 0.033 \\
\hline \multicolumn{5}{|l|}{ Diagnostics } \\
\hline Pseudo $R^{2}$ & $27.2 \%$ & $30.3 \%$ & $30.7 \%$ & $31.4 \%$ \\
\hline Wald test: all coefficients $=0\left(\chi^{2}\right)$ & $21,190^{* * *}$ & $12,078^{* * *}$ & $63,981^{* * *}$ & $9,563^{* * *}$ \\
\hline Correlation of coverage and co-manager equations $(\rho)$ & $0.313^{* * *}$ & $0.103^{* * *}$ & $0.047^{* *}$ & 0.053 \\
\hline Likelihood ratio test of independent equations $(\rho=0)\left(\chi^{2}\right)$ & $160.0^{* * *}$ & $11.4^{* * *}$ & $10.7^{* *}$ & 2.8 \\
\hline
\end{tabular}

